\title{
Morphological Study on the Effect of Polyvinyl Pyrrolidone Infusion upon the Reticuloendothelial System
}

\author{
Mizu Kojima and Kiyoshi Takahashi \\ Department of Pathology (Prof. M. Kojima), \\ Fukushima Medical College, Fukushima \\ Kenji Honda \\ Department of Surgery (Prof. K. Honda), \\ Fukushima Medical College, Fukushima
}

\begin{abstract}
In order to make clear polyvinyl pyrrolidone (PVP) storage in the human body and to see its side-effects, 34 autopsy cases which had received intravenous infusion of various total doses of the substance were submitted to detailed pathological, histochemical and biochemical studies. Clinical symptoms were also taken into consideration in the analysis of the cases. The lesions due to PVP storage were microscopically characterized by proliferation of foam cells, deposition of vacuolar or basophilic substances, occasional appearance of multinuclear giant cells and formation of granulomatous structures in rare instances. These findings were demonstrated in various organs and tissues, especially all over the reticuloendothelial system. PVP storage in the tissue was apparently the stronger in its grade, the larger the total administered dose of the substance was. In the kidney, PVP storage assumed microscopically the feature of a kind of nephrosis. In several cases which had received more than $200 \mathrm{~g}$ of PVP of intermediate molecular weight in total, heavy storage of the substance developed throughout the reticuloendothelial system and in the kidney. In such cases, it seemed probable that heavy PVP storage exerted unfavorable effects on the organism through blockade of the reticuloendothelial system, impairment of resistance capacity, retardation in the repair of inflammation or surgical wounds, promotion of already present cancerous growth or damage of renal tissue.
\end{abstract}

Polyvinyl pyrrolidone (PVP) is a macromolecular compound which was first synthesized by Reppe in Germany during the World War II..$^{1,2}$ Since Hecht and Weese $^{4}$ in 1943 introduced this compound as an excellent plasma substitute into medical use, it has widely been employed in European countries and in recent years in Japan, with alleged good clinical results. ${ }^{3}$ The average molecular weights of PVP used for the purpose of medical treatment are 40,000 (high molecular PVP), 24,800 (intermediate molecular one) and 12,600 (low molecular

Received for publication, January 9, 1967. 
one). High molecular PVP in general is intraperitoneally infused to prevent the development of tissue adhesions at abdominal surgery. The intermediate molecular PVP is intravenously infused as a blood volume expander for preventing shock at surgery, trauma, hemorrhage, burn, dehydration or mechanical injuries. Low molecular PVP is almost exclusively used as a detoxicating agent in various infectious diseases and other diseases associated with release of toxic substances, as well as a diuretic against edema in chronic nephritis or nephrosis.

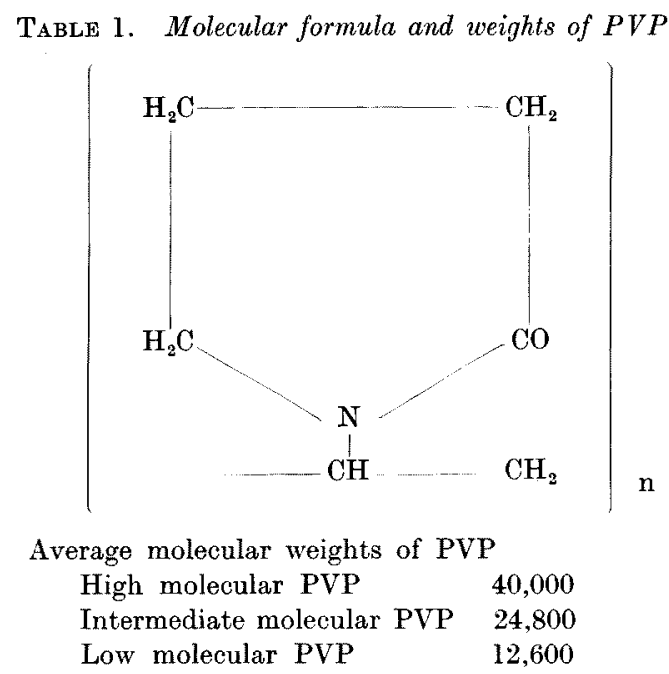

Now, with increasing use of PVP it has become a matter of concern, whether in cases of repeated intravenous PVP infusions the compound is excreted by the kidney or not. The problem has been investigated through clinical and experimental approaches by many research workers, but remains at present still unsolved. Some of the workers emphasized that PVP, when administered, was completely excreted by the kidney in a short time. However, a special regard should be paid to the results of experimental studies ${ }^{5-7}$ presented by others that the renal excretion of the PVP was only incomplete, in particular when high or intermediate molecular PVP was infused. Furthermore, it should be pointed out that macromolecular substances produced by polymerization of such vinyl compounds as PVP cannot be metabolized in the body.

In view of such experiences, it is possible that a variety of macromolecular substances are retained in the body. In an attempt to settle this problem, many animal experiments have been carried out,,$^{5-21}$ but for the most parts they have been conducted from biochemical and physiological viewpoints. On the other hand, the thesaurosis or storage disease that may follow intravenous PVP infusion, so far as we know, has hitherto been reported merely by a small number of workers mostly in Germany, ${ }^{21-26}$ and relatively little is known about the relation between the total administered dose of PVP and the development of thesaurosis 
on the histological level. ${ }^{26}$ Because of the paucity of information about this problem, morphological changes resulting from the parenteral administration of such macromolecular substances as PVP have been poorly explored in the field of pathological anatomy, and the influence of PVP administration on the human body, which is also an important clinical problem, remains still almost unsettled.

In view of this lack of pertinent knowledge, the present study is undertaken on 34 autopsy cases which had received PVP, with the purpose of describing manifold morphological findings of the storage phenomenon and examining the influence of PVP administration on the human body.

\section{Materials and Methods}

For the present study, 34 autopsy cases which had received intravenous PVP injection were examined. In 27 out of the 34 cases, various total doses of intermediate molecular PVP had been intravenously administered, and in the remaining 7 cases low molecular PVP had been given. This study, therefore, was mainly made on the observation of the 27 cases infused with intermediate molecular PVP, and the 7 cases of low molecular PVP were used for comparison. In each case, all pertinent clinical data and autopsy findings were examined in detail. Histological specimens were taken from as many organs and tissues as possible, especially from those belonging to the reticuloendothelial system, and submitted to the histological study. All these specimens were embedded in paraffin for routine sections. Besides hematoxylin-eosin, PAS and mucicarmin stainings were used. Some of the selected specimens were subjected regularly to Feulgen's reaction, methyl-green pyronine staining, metachromatic reaction with toluidine blue, von Kossa's reaction and various special staining methods for PVP, such as Jancsó's iodine, ${ }^{14}$ Chlorazol fast pink $^{14}$ and Congo red method. ${ }^{22}$ Small pieces of selected specimens were saved for the frozen section and the sections were stained with Sudan III and Sudan black B.

\section{Clinical Findings}

1) Age and sex. The ages of our patients ranged from 4 to 73 years. The great majority of them were adult, one-third of them being in the sixties. The over-all sex incidence showed a predominance of male patients, the male-female ratio being 22 to 12 .

2) Causative diseases. As indicated in Table 2, out of the 34 cases the causative diseases were neoplasmas in 15 cases, including gastric carcinoma in 4 cases, carcinoma of the esophagus in 4, carcinoma of the uterine cervix in 3, rectal carcinoma, choriocarcinoma, spinal cord tumor and acute leukemia in one each. Causative diseases of inflammatory nature, on the other hand, were present in 10 cases, including chronic glomerulonephritis in 3 cases, cardiac failure presumably of rheumatic nature in 3 , diffuse peritonitis in 2, pulmonary abscess and dysentery in one each. The other causative diseases were cerebral hemorrhage in 3 cases, 
TABLE 2. Degrees of PVP storage in various

Group I. Administered with intermediate molecular PVP

\begin{tabular}{|c|c|c|c|c|c|}
\hline $\begin{array}{l}\dot{0} \\
z \\
\dot{8} \\
0 \\
0\end{array}$ & $\stackrel{80}{4}$ & 离 & Causative diseases & 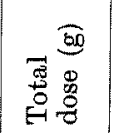 & 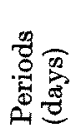 \\
\hline 1 & 64 & 8 & Postoperative fatal hemorrhage & 4 & 2 \\
\hline 2 & 44 & P & Cervical carcinoma of uterus (recurrence) & 7 & 7 \\
\hline 3 & 73 & P & Cervical carcinoma of uterus & 8 & 8 \\
\hline 4 & 34 & q & Choriocarcinoma & 14 & \\
\hline 5 & 22 & $\delta$ & Ruptured aneurysm of $\mathrm{A}$. cerebri media & 16.5 & 6 \\
\hline 6 & 26 & $\delta$ & Mitral stenoinsufficiency & 17.5 & 1 \\
\hline 7 & 36 & 우 & Mitral stenoinsufficiency & 17.5 & 1 \\
\hline 8 & 62 & $\$$ & Gastric carcinoma & 17.5 & 1 \\
\hline 9 & 12 & $\beta$ & Acute leukemia & 26 & 26 \\
\hline 10 & 66 & $\hat{o}$ & Gastric carcinoma, panperitonitis & 35 & 2 \\
\hline 11 & 18 & $\hat{o}$ & Malformation of heart & 35 & 2 \\
\hline 12 & 61 & q & Cerebral hemorrhage & 57 & 57 \\
\hline 13 & 60 & 8 & Carcinoma of esophagus & 70 & 4 \\
\hline 14 & 19 & q & Mitral and aortic stenoinsufficiency & 70 & 4 \\
\hline 15 & 63 & \& & Carcinoma of esophagus & 83 & 50 \\
\hline 16 & 56 & $\hat{o}$ & Gastric carcinoma & 87.5 & 5 \\
\hline 17 & 26 & $\delta$ & Rectal carcinoma (recurrence) & 105 & 6 \\
\hline 18 & 63 & $\delta$ & Ruptured aortic aneurysm & 105 & 6 \\
\hline 19 & 65 & $\delta$ & Gastric carcinoma (recurrence) & 122.5 & 7 \\
\hline 20 & 73 & $\delta$ & Cerebral softening & $147^{\circ}$ & 42 \\
\hline 21 & 38 & q & Cervical carcinoma of uterus & 193 & 81 \\
\hline 22 & 36 & $\hat{0}$ & Postoperative diffuse peritonitis & 210 & 12 \\
\hline 23 & 41 & 古 & Spinal cord tumor & $279.5^{*}$ & 35 \\
\hline 24 & 29 & P & Postoperative diffuse peritonitis & 395.5 & 25 \\
\hline 25 & 67 & $\delta$ & Carcinoma of esophagus & 490 & 28 \\
\hline 26 & 35 & $\hat{o}$ & Pulmonary abscess & 546 & 49 \\
\hline 27 & 61 & $\hat{s}$ & Carcinoma of esophagus & 1015 & 58 \\
\hline
\end{tabular}

Group II. Administered with low molecular PVP

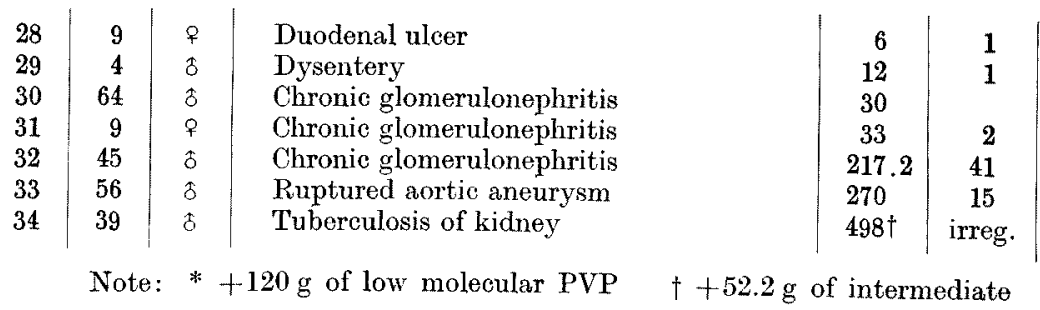

ruptured aortic aneurysma in 3, cerebral softening, fatal postoperative hemorrhage, duodenal ulcer and malformation of the heart in one each.

3) Administration and dosage of PVP. As shown in Table 2, the total doses of intermediate molecular PVP administered in the 27 cases ranged from 4 to $1,015 \mathrm{~g}$ and were less than $70 \mathrm{~g}$ in 12 cases, 70 to $199 \mathrm{~g}$ in 9,200 to $349 \mathrm{~g}$ in 2 and more than $350 \mathrm{~g}$ in 4 . Out of all these cases, the last 6 cases which received intravenous infusion of more than $200 \mathrm{~g}$ of PVP in total are considered to be the most valuable examples, because they exhibited heavy storage of PVP all over the reticuloendothelial system and in the kidneys. 


\begin{tabular}{|c|c|c|c|c|c|c|c|c|c|c|c|c|c|c|}
\hline 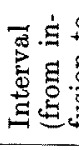 & 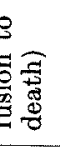 & $\frac{8}{3}$ & $\frac{\overrightarrow{8}}{\frac{d}{2}}$ & 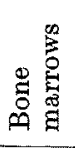 & 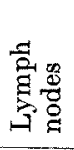 & 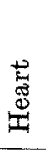 & $\begin{array}{l}D_{0} \\
\stackrel{8}{5} \\
5 \\
\exists\end{array}$ & 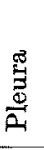 & $\begin{array}{l}\frac{0}{73} \\
\stackrel{3}{9} \\
\Leftrightarrow\end{array}$ & 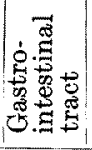 & 胥 & 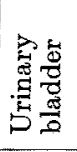 & 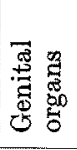 & $\frac{\infty}{\frac{\infty}{0}}$ \\
\hline $3 \mathrm{~m}$ & $28 \mathrm{~d}$ & - & - & - & + & + & - & - & - & + & + & + & + & + \\
\hline & 17 & - & - & - & + & - & - & - & - & - & - & + & - & \\
\hline 6 & 17 & - & - & - & - & - & - & - & & $H$ & & $H$ & + & + \\
\hline 2 & 12 & + & + & - & + & - & + & - & + & - & - & & + & - \\
\hline 4 & 11 & + & - & - & - & - & - & - & - & - & - & - & - & - \\
\hline & 1 & - & - & - & + & + & - & - & - & & & - & - & - \\
\hline & 1 & - & - & - & - & - & - & - & & & & & - & - \\
\hline & 1 & $H$ & - & - & - & + & - & - & + & & + & & & + \\
\hline 1 & & - & - & - & + & - & - & - & - & + & - & & - & + \\
\hline & 14 & + & - & + & + & - & + & - & & & + & - & - & + \\
\hline & 3 & - & - & - & - & - & - & - & & - & - & - & - & - \\
\hline 1 & 27 & $\#$ & - & - & + & - & - & - & + & & - & - & - & - \\
\hline & 9 & + & - & + & + & + & + & + & & + & & & + & - \\
\hline 5 & 23 & + & + & Ht & + & $H$ & + & + & + & + & $\rightarrow$ & $\#$ & + & \\
\hline 1 & 20 & H & + & HI & \# & - & + & - & + & + & - & - & - & - \\
\hline & 5 & + & - & + & + & - & + & - & & & + & - & - & - \\
\hline & 26 & \# & - & + & + & + & + & - & + & + & + & + & + & + \\
\hline 3 & 27 & H & $H$ & + & $H$ & - & - & - & + & - & $\rightarrow$ & & + & - \\
\hline 2 & & + & H & \# & $H$ & - & + & - & + & - & + & - & + & + \\
\hline 4 & & + & $H$ & + & + & - & - & - & + & + & - & - & + & + \\
\hline 2 & 21 & $H$ & $H$ & $H$ & \# & + & $H$ & - & $H$ & + & + & $\#$ & + & $t$ \\
\hline 2 & & 世 & \# & \# & WI & + & + & - & & $H$ & & & & + \\
\hline 7 & 24 & $H$ & $H$ & \# & $\#$ & + & $H$ & + & $H$ & + & + & $H$ & $H$ & - \\
\hline 2 & 26 & H & \# & \# & H & + & $\ddot{t}$ & $H$ & $H$ & $H$ & & $H$ & - & H \\
\hline 2 & 27 & 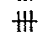 & $H$ & \# & $\mathrm{H}$ & - & + & + & & + & + & - & + & + \\
\hline 3 & 27 & $H$ & H & III & 册 & H & 册 & + & + & + & - & + & + & + \\
\hline 3 & 13 & $H$ & $H$ & $H$ & H & H & H & + & $H$ & + & + & + & + & + \\
\hline & 2 & - & - & - & - & - & - & - & - & - & - & - & - & - \\
\hline & 4 & - & - & - & - & - & - & - & & - & - & & & - \\
\hline & 20 & + & - & - & + & + & + & - & - & + & - & + & - & + \\
\hline & 2 & - & - & $\rightarrow$ & - & - & + & - & - & - & - & - & - & - \\
\hline $\operatorname{lm}$ & 8 & H & $\#$ & + & + & -1 & + & - & - & + & - & - & - & - \\
\hline & 15 & + & - & - & - & - & - & - & - & & - & & & - \\
\hline & $?$ & H & + & $H$ & $H$ & - & + & - & & + & + & + & + & - \\
\hline
\end{tabular}

molecular PVP.

The intervals from the beginning of intravenous infusion of PVP to death varied considerably from case to case, being within a few days in 6 cases, within a week in 4 , less than 2 months in 4 , less than 4 months in 9 and more than 4 months in 4 . The longest interval was about 8 months in a case.

\section{Pathological Findings}

\section{Macroscopic Findings}

At autopsy, the gross findings which could be attributed to PVP storage were in general not conspicuous enough to be distinguished from the findings which may 
otherwise be induced by causative diseases, with the exception of several cases of large total PVP doses, especially of cases of more than $200 \mathrm{~g}$, in which some noteworthy gross findings were obtained, particularly in the organs of the hematopoietic system.

Generally speaking, the spleen showed a slight enlargement almost in all these cases, but the weight was mostly limited to twice the normal weight. The consistency was somewhat soft. On section, the splenic tissue was somewhat frail to tough and exhibited an obscured gross architecture due to pulpal byperplasia and follicular atrophy. The liver showed no particular enlargement that could be attributed to the agent, but its sectional surface displayed an obscurity of the lobular marking. The lymph nodes appeared occasionally enlarged, though moderate in degree.

\section{Microscopic Findings}

1) Fundamental changes. At the beginning of this chapter, the fundamental microscopical changes of PVP storage phenomenon will be described. In general, when a solution containing PVP is intravenously injected, the reticuloendothelial cells take up actively macromolecular particles of PVP from the blood stream or body fluids, become remarkably swollen, reactively proliferate and are subsequently transformed into large foam cells. Therefore, it will be easily comprehended that the distribution of the foam cells is essentially the same as that of cells belonging to the reticuloendothelial system or of cells positive for vital staining. This change is considered to be the fundamental process of the thesaurosis. Moreover, when the storage in such foam cells became remarkable with increasing total doses of PVP, numerous clumps of vacuolated or basophilic massive substance were found deposited in various organs and tissues, particularly all over the reticuloendothelial system. In addition, in many cases of heavy PVP stroage, lesions composed of a large number of proliferating foam cells and of vacuolar massive deposits were frequently associated with appearance of numerous multinuclear giant cells and sometimes with granulomatous changes similar to those of foreign body type.

a) Foam cells. As already stated in the preceding section, proliferation of foam cells was the basic histological change. The majority of the foam cells were large in size and round in shape, with an abundant foamy cytoplasma. The cells usually had a vesicular nucleus, so that they closely resembled other kinds of foam cells appearing in various xanthomatoses ${ }^{27}$ or other storage diseases. ${ }^{39}$ However, a number of foam cells were polygonal, fusiform or reticular in shape. All these foam cells contained varying numbers of fine or coarse granules, or small vacuolar masses of polymorphic configuration in their cytoplasma. In the routine sections, the contents of these fine and coarse phagocytic granules had been dissolved and extracted in the processes of fixation and embedding, so that all these cells had a foamy appearance after ordinary stains. For the same reason, the granules were not very well stained, even when various special staining methods for PVP were applied. But the small vacuolar masses phago- 
cytized by the foam cells and amorphous, massive deposits in tissues were stained orange brown with Jancsó's iodine method, pinkish red with Chlorazol fast pink and red with Congo red. On the basis of these findings and because PVP-like material was not stained with Sudan III and Sudan black B in the formalin-fixed frozen section, the PVP-storing foam cells were easily distinguished from those in xanthomatous diseases. ${ }^{27}$ With the periodic acid-Schiff technique, the phagocytic granules or vacuolar massive deposits were not stained. On the Prussian blue reaction, the foam cells were not stained except for those present in blood-destroying organs such as the liver or spleen.

Generally spealing, the foam cells proliferate and increase in number roughly proportional to the total doses of PVP given. In the foam cells, fine granules appeared predominantly in the early phase, or in cases administered with a small total dose. With increasing total doses of PVP, coarse granules gradually increased in number among the phagocytized particles and fused with one another, in consequence growing to small vacuolar masses. Finally, the foam cells laden with a large amount of these granules lost their nuclei and were subsequently transformed into pieces of massive vacuolar substance simulating primary extracellular deposits. On the other hand, with the lapse of time following the last intravenous infusion of PVP, the foam cells decreased in number, diminished in size and finally almost completely disappeared in several months.

b) Massive deposits. In the routine sections, the massive deposits were found in the form of vacuolar amorphous clumps, extremely variable in size, and round, oval or irregular in shape. On some occasions, they fused with one another and accumulated in some areas, consequently developing to a large confluent amorphous uni- or multilocular vacuolar mass. In particular, heavy PVP storage often produced lesions with circumscribed accumulation of a huge quantity of the massive deposits mostly with basophilic staining behavior, intermingled with a number of multinuclear giant cells in rare instances.

As for the mechanism of development of the massive deposits two different processes were apparently acceptable. Namely, the one was the transition of foam cells to clumps of phagocytized substance, and the other primary extracellular deposition.

c) Basophilic substance. The 'basophilic substance' is the term applied to the phagocytic granules in the foam cells and the massive, amorphous deposits, all of which were stained bluish in the ordinary hematoxylin stain. Most of the phagocytic granules and small massive substances, when stained uniformely bluish, were closely simulant of the so-called hematoxylin bodies as usually seen in lupus erythematosus. Large massive deposits, however, presented a vacuolar appearance possessing a basophilic margin. The basophilic feature of the stored PVP-like materials began usually to appear approximately one month after the last intravenous infusion of PVP and thereafter increased gradually in intensity with the lapse of time. In sections of the formalin-fixed tissues, the basophilic substance was negative for Feulgen's reaction for DNA, methyl-green pyronine 
staining, metachromatic reaction with toluidine blue, von Kossa's method for calcium, mucicarmin staining, iron reaction with Prussian blue and hemoglobin staining, and also for the periodic acid-Schiff staining.

d) Giant cells. A heavy PVP storage phenomenon was furthermore characterized by appearance of numerous multinuclear giant cells. The giant cells usually possessed irregularly shaped abundant cytoplasma loaded with numerous fine or coarse granules and with confluent small masses of polymorphic configuration, which occasionally displayed basophilic tinge. Most of the cells had numerous small nuclei which were arranged irregularly, bearing a close resemblance to those of foreign body type. In addition, the giant cells in some area appeared to be extremely variable in size and irregular in shape, sometimes presenting a grotesque appearance. In the multinuclear giant cells, in particular when they contained a large amount of basophilic substance, their nuclei became difficult to distinguish from the phagocytized basophilic granules or masses in the ordinary stain. On the other hand, there sometimes appeared other types of giant cells having vesicular nuclei in their abundant foamy cytoplasma.

The development of all these giant cells was closely related to the total doses of PVP, and they were especially notable in almost all cases receiving more than $200 \mathrm{~g}$, and tended to appear predominantly in the lymphoreticular tissues.

e) Granulomatous lesions. In many cases exhibiting a marked PVP thesaurosis, numerous histiocytes and foam cells were often found to lie in fairly well circumscribed groups with a large quantity of the massive vacuolar deposits and with variable numbers of the multinuclear giant cells, giving the infiltrate a granulomatous feature. These granulomatous lesions might be sometimes accompanied by slight inflammatory infiltrates composed mainly of lymphocytes, plasma cells or leukocytes.

2) PVP storage phenomenon in various organs and tissues. The afore-mentioned fundamental microscopical changes resulting from repeated intravenous infusion of PVP were observed in various organs and tissues, especially throughout the reticuloendothelial system, and varied considerably in their intensity according to individual organs and tissues, occasionally disclosing variegated peculiar findings.

Liver. In the liver, Kupffer's cells usually played an important role in PVP storage. In the ordinary stain, the earliest microscopical changes of the liver were fine vacuolation and ballooning of Kupffer's cells. In most cases infused with more than $70 \mathrm{~g}$ of PVP in total such changes were distinctly observed with remarkable transformation of Kupffer's cells into foam cells. In the foam cells, coarse phagocytic granules increased in number and gradually grew up to small vacuoles of polymorphic shapes. In the sinusoids, the foam cells proliferated in increasing numbers roughly in parallel with the total doses of PVP. They were found in a large number particularly in almost all the cases administered with more than $200 \mathrm{~g}$ and were accompanied occasionally by a number of mutinuclear 
giant cells and barely granulomatous lesions.

The hepatic parenchymal cells contained also numerous round vacuolar intracytoplasmic particles regarded as PVP-like material. The granules often showed a slight basophilic tinge, which was an especially constant observation in almost all cases of long intervals after the final PVP infusion. In some examples of prominent intrasinusoidal storages, there were in places observed marked atrophy, degeneration and occasional disappearance of hepatic cells. It is noteworthy that in one case the liver showed extensive, diffuse proliferation of foam cells, resulting in considerable distortion of the normal hepatic structures.

The Glisson's sheath was rarely involved in the storage. In cases o positive storage, it was mostly represented by slight deposition of massive vacuolar substances, generally with basophilic feature. In only one case chronic cholangitis was associated with marked periductal storage of PVP-like material. ${ }^{23}$

Next, we will present an autopsy case with marked hepatic involvement.

Case 21. A 38-year-old woman underwent radical hysterectomy with bilateral oophorectomy and radiation therapy with ${ }^{60} \mathrm{Co}$ against carcinoma of the uterine cervix. For 81 postoperative days, the patient received repeated intravenous infusions of $193 \mathrm{~g}$ of PVP in total. A week prior to death, she developed severe generalized jaundice, high fever and unconsciousness and then expired approximately 2 months and 21 days after the beginning of PVP infusion.

Postmortem examination presented heavy PVP storage throughout the reticuloendothelial system, especially severe in the spleen, lymph nodes, bone marrows and connective tissues. In the liver, the storage had adranced so far that the normal hepatic structure was almost completely replaced by extensive diffuse proliferation of foam cells and by deposition of vacuolar masses. Hepatic cells revealed likewise marked dissociation and vacuolation with a large amount of PVP-like material. Additional microscopical findings were disseminated foci of bile duet proliferation mainly in Glisson's sheaths and occasionally in the hepatic lobules.

In this case, it is obvious that the hepatic involvement in heavy PVP storage is the primary cause of death. The clinical course of this case was that of acute yellow atrophy of the liver.

Spleen. Morphological response of the spleen to PVP administration was somewhat retarded in comparison with that of the liver and lymph nodes. The initial changes of the spleen occurred mainly in the red pulp, especially in the venous sinuses, which were lined with numerous swollen foamy endothelial cells as a result of active phagocytosis of macromolecular particles. On the other hand, the reticulum cells in the medullary cords had a less distinct tendency to phagocytize the particles and to be transformed into the foam cells, although the fixed type reticulum cells contained a certain number of the granules in the cytoplasma. However, in most cases infused with more than $100 \mathrm{~g}$ of PVP in total, foam cells proliferated notably not merely in the venous sinuses, but also appeared in the medullary cords. These changes became more remarkable with increasing total doses of PVP administered, substituting almost completely the normal pulpal structures. Massive vacuolar PVP-like substances were 
extracellularly deposited on occasions, and there appeared in rare instances a number of multinuclear giant cells.

Contrary to the hyperplastic changes of the red pulp, the lymph follicles appeared rather atrophied, where varying amounts of vacuolar mass, sometimes basophilic, were present. The basophilic change of PVP-like substance appeared earlier in the lymph follicles than in the red pulp.

Bone marrows. In one of the 3 cases administered with $35 \mathrm{~g}$ of PVP in a total dose, a small number of PVP-like particles were demonstrated confined to swollen reticulum cells. In all the cases of more than $70 \mathrm{~g}$ of PVP, the reticulum cells became swollen, filled with numerous fine or corase PVP-like granules and were transformed apparently into typical foam cells. The foam cells increased in number roughly in parallel with increasing total doses of PVP. Finally, the bone marrow structure of all cases of more than $200 \mathrm{~g}$ of PVP were almost completely replaced by a tremendous number of the foam cells. In contrast with the pronounced foam cell storage, any massive extracellular substance, vacuolated or basophilic, deposited not so remarkably as usually seen in the other organs and tissues, and the multinuclear giant cells developed likewise only infrequently.

Generally speaking, the intracellular storage of PVP was more remarkable in the red marrows than in the fatty marrows. However, even in the latter foam cells proliferated in varying numbers when PVP had been given in a large amount. They were distributed especially in perivascular areas, and may be thought to have originated from perivascular histiocytes. The sinusoidal reticuloendothelia in general did not participate in the storage.

Lymph nodes. Generally speaking, the lymph node was one of those organs which intensely reacted to PVP infusion. Already in 4 of 6 cases, in which a total PVP dose of $20 \mathrm{~g}$ had been given, a small number of foamy reticulum cells proliferated mainly within the lymph sinuses, particularly in the subcapsular region, but also often in the medullary cords. They had relatively little tendency to become free rounded foam cells. Furthermore, roughly in parallel with the total PVP doses the tissues were occupied by aggregates of foam cells and deposition of vacuolar masses. The storage was most prominent in the lymph sinuses and medullary cords, although the normal structural framework remained intact. In heavy PVP storage, these changes occurred even in the lymphatic follicles, and less frequently in the germinal centers with reduced intensity. Moreover, multinuclear giant cells laden with numerous fine or coarse granules and small vacuolar masses, often with basophilic tinge, appeared dispersedly or fairly well grouped, especially marked in all the 6 cases of more than $200 \mathrm{~g}$ of PVP in total. Granulomatous lesions were occasionally found in association with the storage.

In addition, a marked infiltration of plasma cells was usually seen in all the cases of heavy PVP storage, and even in some cases in which no inflammatory foci were demonstrated at autopsy. 
Connective tissues. The connective tissues, all in the subcutaneous, interstitial or other parts, had diffuse infiltration and proliferation of foamy histiocytes with varying amounts of PVP-like material, as well as occasional deposition of extracellular vacnolar masses, either vesicular or basophilic. The basophilic substance usually appeared so remarkably as in the lymph nodes, but multinuclear giant cells were infrequent.

Heart. In the heart, PVP storage occurred slightly in general, but often notably in subpericardial fatty tissues, which were infiltrated in some cases by numerous foamy histiocytes, or deposited in other cases with varying numbers of massive vacuoles, mostly basophilic. In some instances, the myocardium contained numerous vacuolar masses of varying sizes and irregular shapes distributed separately or united to clusters among the muscle fibers. This finding seems to correspond to that of 'periston myocardosis' previously described by Wrage. ${ }^{18}$ Except for a case in which a small number of basophilic vacuoles were barely found to be deposited in the subendothelial or subendocardial layers, there was in general no storage of PVP-like material in the endocardium. The valvular system was not involved in storage.

Lungs. On occasion, varying numbers of large foam cells appeared diffusely distributed or fairly well grouped particularly within the intraalveolar spaces and also in the alveolar walls. Therefore, the foam cell storage phenomenon, when it occurred widely, displayed a microscopical picture closely resembling that of lipid pneumonia. And this picture was observed in 2 of the 4 cases infused with more than $350 \mathrm{~g}$ of PVP in total. It was especially severe in one case of a male of 35 years of age with pulmonary abscess (Case 26).

Other organs and tissues. The gastrointestinal tract was found to have varying amounts of irregularly stored PVP-like material, though generally slight in degree. In the pancreas, foamy histiocytes were often found dispersedly in the interstitial connective tissue.

The genital organs in general revealed a slight storage of PVP comparable with the other organs and tissues noted above. The storage often involved vaginal walls, uterine cervices, testicles and prostatic glands. However, we could not find out any storage in the ovary and corpus of the uterus throughout examined cases.

In the adrenal glands, the sinusoidal reticuloendothelia became markedly ballooned by phagocytized PVP-like particles and reactively proliferated. Their transformation into the foam cells were evidently demonstrable here and there in the sinusoids, while the basophilic vacuolar masses were rarely deposited. The thyroid and pituitary glands, however, were not involved in the storage at all.

Kidneys. Apart from the remarkable involvement of the reticuloendothelial system in PVP storage, other noteworthy changes were observed in the kidney. The findings are briefly summarized in Table 3. As shown clearly in this table, in all cases injected with 17.5 to $35 \mathrm{~g}$ of PVP in total doses, vacuolar swelling first 
TABLE 3. Histological changes of kidneys in 27 autopsy cases administered with intermediate molecular PVP

\begin{tabular}{|c|c|c|c|c|c|c|c|c|c|c|c|c|c|}
\hline \multirow[b]{2}{*}{ 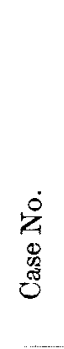 } & \multicolumn{4}{|c|}{$\begin{array}{l}\text { Administration } \\
\text { methods }\end{array}$} & \multicolumn{4}{|c|}{ Glomerular changes } & \multicolumn{5}{|c|}{ Tubular vacuolation } \\
\hline & 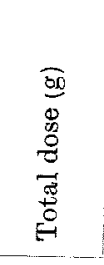 & $\begin{array}{c}0 \\
0 \\
0 \\
0 \\
0 \\
0 \\
0 \\
0 \\
0 \\
0 \\
0\end{array}$ & 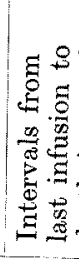 & 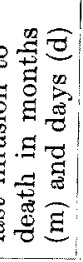 & 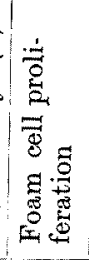 & 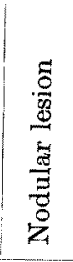 & 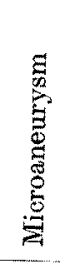 & 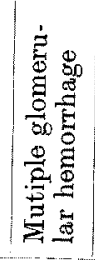 & 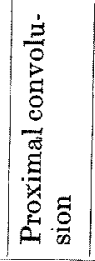 & 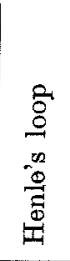 & 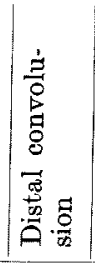 & 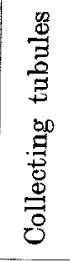 & 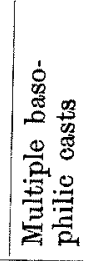 \\
\hline 1 & $4 \mathrm{~g}$ & $2 d$ & $3 \mathrm{~m}$ & a $26 \mathrm{~d}$ & - & - & - & - & - & - & - & - & - \\
\hline 2 & 7 & $7 !$ & & 17 & - & - & - & - & - & - & - & - & - \\
\hline 3 & 8 & 8 & 6 & 17 & - & - & - & - & - & - & - & - & - \\
\hline 4 & 14 & & 2 & 12 & - & - & - & - & - & - & - & - & - \\
\hline 5 & 16.8 & 6 & 4 & 5 & - & - & - & - & + & + & - & - & + \\
\hline 6 & 17.5 & 1 & & 1 & - & - & - & - & + & $H$ & - & - & + \\
\hline 7 & 17.5 & 1 & & 1 & - & - & - & - & - & + & - & - & - \\
\hline 8 & 17.5 & 1 & & 1 & - & - & - & - & $H$ & $H$ & + & - & - \\
\hline 9 & 26 & 26 & & 4 & - & - & - & - & + & + & - & - & + \\
\hline 10 & 35 & 2 & & 11 & - & - & - & - & - & - & + & - & + \\
\hline 11 & 35 & 2 & & 1 & - & - & - & - & + & $H$ & - & - & + \\
\hline 12 & 57 & 57 & & 0 & - & - & - & - & - & + & + & - & + \\
\hline 13 & 70 & 4 & & 5 & - & - & - & - & - & - & - & - & + \\
\hline 14 & 70 & 4 & 5 & 19 & - & - & - & - & + & + & + & $\ldots$ & + \\
\hline 15 & 83 & 50 & & 0 & H & + & - & - & + & + & H & + & H \\
\hline 16 & 87.5 & 5 & & 0 & - & - & - & - & - & - & H & - & H \\
\hline 17 & 105 & 6 & & 21 & - & - & - & - & - & - & \# & - & + \\
\hline 18 & 105 & 6 & 3 & 20 & - & - & - & - & - & - & + & - & + \\
\hline 19 & 122.5 & 7 & 1 & 23 & - & - & - & - & - & - & H & - & H \\
\hline 20 & 147 & 42 & 2 & 18 & - & - & - & - & + & + & + & - & + \\
\hline 21 & 193 & 81 & & 0 & + & - & - & + & - & - & H & + & $H$ \\
\hline 22 & $210 *$ & 12 & 1 & 18 & - & - & - & - & H & H & H & H & $H$ \\
\hline 23 & 275.5 & 35 & 6 & 20 & - & - & - & - & $\#$ & H & \# & H & $H$ \\
\hline 24 & 395.5 & 25 & 2 & 1 & H & $H$ & $H$ & - & $H$ & \# & H & 世 & \# \\
\hline 25 & 490 & 28 & 2 & & H & - & - & - & + & $H$ & H & H & Ht \\
\hline 26 & 546 & 49 & 1 & 8 & H & - & - & - & H & H & 卅 & $H$ & \# \\
\hline 27 & 1,015 & 58 & 1 & 15 & H & - & - & + & \# & H & $\#$ & H & H \\
\hline
\end{tabular}

appeared in the epithelial cells of the distal portion of the Henle's loop and of the proximal convolution of the renal tubules. All these cases had undergone surgical treatments and received intravenous infusion of PVP a few days before death. Except in these cases, the initial storage change was characterized by vacuolar swelling of the tubular epithelial cells of the distal convolution in almost all the cases infused with more than $70 \mathrm{~g}$ of PVP in total. When numerous basophilic casts were simultaneously formed in this portion of the kidney and obstructed almost completely the tubular lumens, the vacuolar swelling of the epithelial cells gradually extended from this portion and ascended to the distal portion of the Henle's loop and further to the proximal convolution roughly in proportion to the total dose of PVP administered. Especially in all cases of more than $200 \mathrm{~g}$ of PVP, the vacuolar swelling and degeneration were remarkable in the epithelial cells 
over the entire length of the tubules with formation of basophilic casts. In the ordinary stain, the tubular epithelial cells contained fine or coarse intracytoplasmic PVP granules, among which basophilic granules were sometimes present.

The glomeruli showed a slight mesangial thickening as an initial change, occasionally with deposition of coarse granules or small vacuolar masses. Furthermore, foam cells proliferated nodularly grouped or scattered in the glomeruli. They were especially marked in all the 4 cases infused with more than $350 \mathrm{~g}$ of PVP in total. The foam cells contained fine or coarse granules or minute vacuoles and were confirmed to have originated from the endothelial cells of glomerular capillaries. As additional findings nodular lesions closely resembling those in the Kimmelstiel-Wilson syndrome were noted in 2 cases, in one of which the lesions were associated with microaneurysms of the glomerular tufts. Multiple glomerular hemorrhages were also noted in 2 cases.

Nervous tissues. There was no noteworthy change induced by PVP storage in the central nervous system, whereas a slight proliferation of foam cells and deposition of extracellular vacuoles were often observed in the peripheral nerve tissues.

3) PVP storage phenomenon in infammatory foci and surgical wounds. As indicated in Table 4, of 27 cases receiving intravenous infusion of intermediate molecular PVP, 16 cases had various inflammatory causative diseases or com-

TABLE 4. Comparison of the degree of PVP storage in inflammatory lesions with that in reticuloendothelial system in 16 cases of the group $I$ alministered with intermediate molecular $P V P$.

\begin{tabular}{|c|c|c|c|c|}
\hline $\begin{array}{l}\text { Case } \\
\text { No. }\end{array}$ & $\begin{array}{c}\text { Total } \\
\text { dose }(g)\end{array}$ & Inflammatory lesions & & RES \\
\hline 1 & 4 & $\begin{array}{l}\text { Severe necrotic gangrenous inflammation of anastomosed } \\
\text { parts between the ileum and rectum, and between the ute- } \\
\text { rine cervix and urinary bladder. Purulent pyelonephritis. }\end{array}$ & H & + \\
\hline 2 & 7 & Chronic pyelonephritis. & + & + \\
\hline 3 & 8 & $\begin{array}{l}\text { Localized fibrous-adhesive peritonitis. Ulcerative } \\
\text { necrotizing cystitis. }\end{array}$ & $H$ & + \\
\hline 10 & 35 & Chronic diffuse fibrous peritonitis. & H & + \\
\hline 14 & 70 & Chronic eystitis. & H & H \\
\hline 15 & 83 & Hemorrhagic erosive esophagitis. Chronic gastritis. & 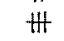 & H \\
\hline 17 & 105 & $\begin{array}{l}\text { Localized purulent peritonitis. Purulent pyelonephritis } \\
\text { and chronic ureteritis. }\end{array}$ & \# & H \\
\hline 18 & 105 & Chronic tonsillitis, duodenitis and pyelitis. & - & \# \\
\hline 19 & 122.5 & Chronic perisplenitis. & $H$ & \pm \\
\hline 21 & 193 & $\begin{array}{l}\text { Chronic fibrous-adhesive panperitonitis. Hemorrhagic } \\
\text { ulcerative cystitis and pyelonephritis. }\end{array}$ & H & 世 \\
\hline 22 & 210 & Fibrinofibrous diffuse peritonitis. Chronic pyelonephritis. & 册 & H \\
\hline 23 & $279.5 *$ & $\begin{array}{l}\text { Retroperitoneal abscess. Chronic hemorrhagic cystitis } \\
\text { and pyelonephritis. Chronic prostatitis. }\end{array}$ & H & tII \\
\hline 24 & 395.5 & Severe diffuse peritonitis. & Ht & H \\
\hline 25 & 490 & $\begin{array}{l}\text { Chronic fibrous-adhesive diffuse peritonitis. Subphrenic } \\
\text { abscess. }\end{array}$ & $\#$ & 曲 \\
\hline 26 & 546 & Lung abscess. Subphrenic abscess and perispinal abscess. & 册 & 世 \\
\hline 27 & 1015 & chronic cystitis and pyelitis. & + & H \\
\hline
\end{tabular}


plications and corresponding focal inflammatory lesions confirmed at autopsy. The present authors examined microscopically in detail PVP storage in these inflammatory lesions. As a result, some evidence was found that PVP storage developed more prominently in the inflammatory lesions. In general, histiocytes and foam cells proliferated markedly and accumulated in acute inflammatory foci. A large amount of vacuolated or basophilic deposit was present in chronic inflammatory foci, occasionally producing furthermore a complicated granulomatous infiltrate. In addition, acute inflammatory foci with marked PVP storage tended to develop severe necrosis. Thus, the repair process of the inflammatory lesions, both acute and chronic, was markedly retarded by PVP storage, and some of the lesions became even incurable.

In the surgical wounds, similar changes were also demonstrated. Generally speaking, the foam cells predominated in fresh wounds, while varying amounts of the vacuolar or basophilic deposits were present in healing or scarred wounds. As noted in Table 5, out of all the 27 cases 18 had undergone surgical treatments. Out of the surgical cases, wide disruption of the cutaneous incision wounds or of the anastomosed parts occurred postoperatively in 8 cases. Most of such cases had received intravenous infusion of more than $70 \mathrm{~g}$ of PVP in total.

The following case is one of the typical pulmonary abscess with marked PVP storage.

Case 26. A 35-year-old man consulted his plysicians with the complaint of chest pain and high fever. Acute pleuritis was diagnosed and the patient recovered in about two months owing to medical treatments. However, he was admitted to the Fukushima Labour Hosptial in late October, 1962, because he suffered from frequent coughs and blood-streaked sputum. Clinical diagnos.s of pulmonary abscess was establisher on the basis of physical and $x$-ray examinations. During hospitalization, the patient repeatedly received intravenous infusion of intermediate molecular PVP in a total dose of $546 \mathrm{~g}$ for the purpose of detoxication. Despite a long-term administration of various antibiotics, the abscess showed little tendency toward recovery on $x$-ray examinations, and his condition deteriorated gradually. Finally the patient developed paralysis of the lower extremities and died on August 22, 1963, under serious dyspnea, orthopnea and generalized edema.

Autopsy revealed an about fist-sized abscess between the middle and lower lobes of the right lung, which perforated through the diaphragm to form a large subphrenic abscess, and on the other hand extended backwards to the 7th thorac $c$ vertebra to develop an abscess around the spinal cord. These abscess cavities contained a large amount of necrotic and purulent masses and were thickly walled with edematous inflammatory granulation tissue infiltrated by leukocytes, lymphocytes, plasma cells and by numerous proliferating histiocytes and foam cells. In an extensive area around the pulmonary abscess, the alveolar septa and interstitial tissues were found thickened mainly on account of marked proliferation of foam cells and partly with a slight deposition of massive vacuolar substances, so that the alveolar spaces appeared concentrically narrowed. In the alveolar spaces, numerous foam cells were found and scattered multinuclear giant cells were present. Moreover, apart from these storage changes in and around the pulmonary abscess, many foam cells likewise proliferated remarkably in the alveolar spaces throughout all lobes of both lungs. This picture reminded us of that of lipid pneumonia.

In addition, marked PVP storage phenomenon was microscopically observed 


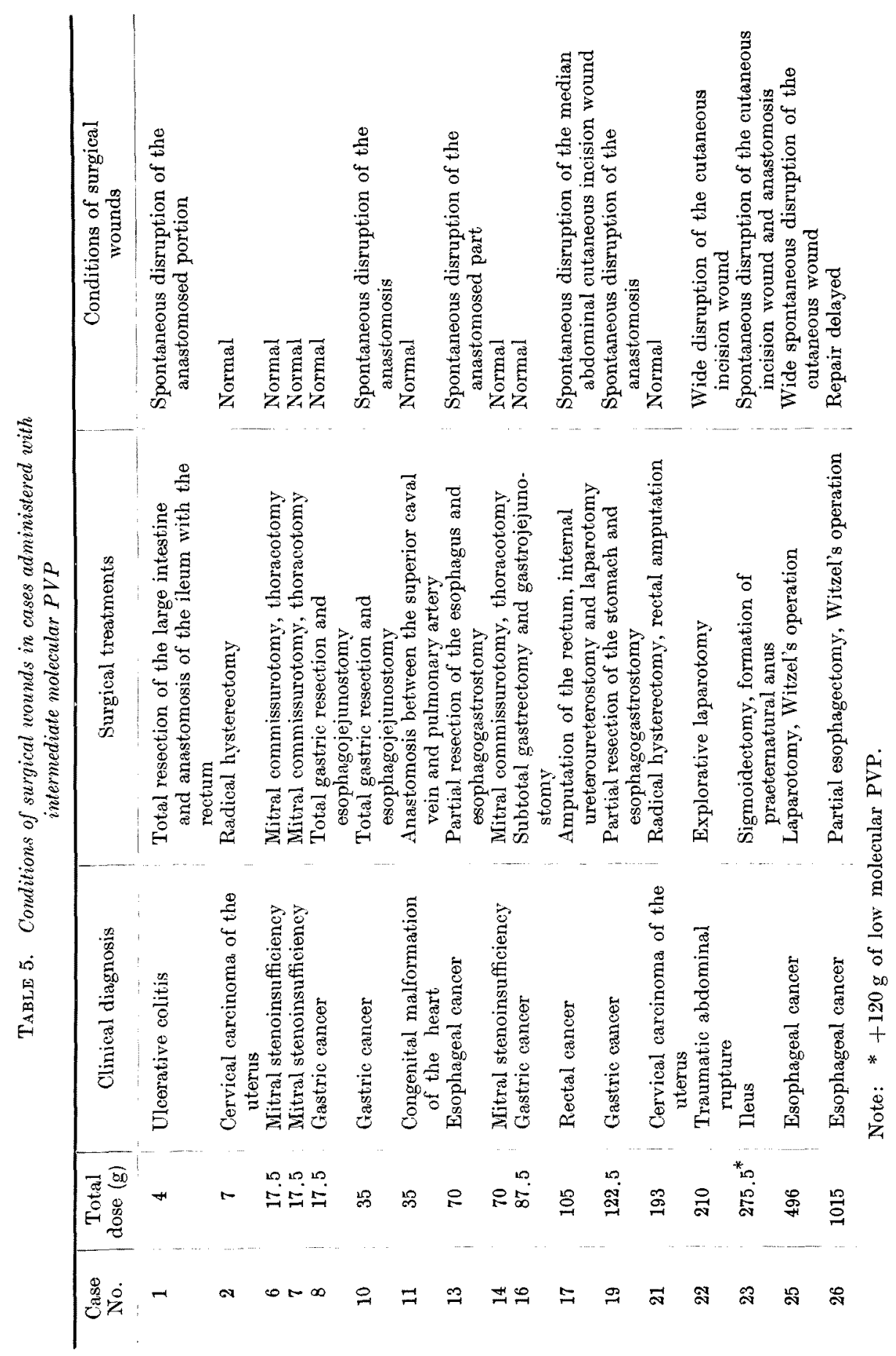


throughout the reticuloendothelial system, particularly in the liver, spleen, lymph nodes and bone marrows and a slight to moderate proliferation of foam cells was noted in the esophageal mucosa, tonsils, intestines, adrenal glands and urinary bladder. The kidneys revealed vacuolar swelling of the tubular epithelia, and mesangial thickening and proliferation of form cells in the glomeruli.

4) PVP storage phenomenon in the stroma of neoplastic lesions. As listed in Table 1, noeplastic diseases were present in 15 cases, of which 13 had carcinomas of various organs. From these cases, we excluded 3, either because they did not develop any metastasis after complete removal of the primary tumor or because they died within short periods after the operation. We microscopically investigated in detail both the primary carcinomas and their metastases in the remaining 10 cases. From the microscopical observations, it was clearly demonstrated that numerous foam cells proliferated mostly in clusters in the stromal connective tissues of the carcinomatous lesions, and that varying quantities of massive vacuoles, almost basophilic, deposited among the collagenous fibers. PVP storage in these lesions was in general extremely variable in degree, but revealed microscopical pictures essentially similar to those of the reticuloendothelial system. Moreover, it is noteworthy that widespread dissemination and multiple cancer metastases were recognized in several cases, particularly marked in some cases infused with large total doses of PVP.

We will describe here a typical example of rectal cancer with generalized cancer dissemination.

Case 17. In October, 1961, a 26-year-old male noticed continuous anal hemorrhage. The patient was referred to the Fukushima Medical College Hospital, where the diagnosis of rectal carcinoma was established. After the admission, he was submitted to rectal amputation and formation of a preternatural anus and received repeated intravenous infusions of PVP in a total dose of $105 \mathrm{~g}$ after the operation. His postoperative course was uneventful and he was discharged 2 months after the operation. In August, 1963, the patient was re-admitted to the hospital with the chief complaint of lumbar pain. A recurrence of rectal carcinoma was suspected. Two weeks after the readmission, urinary retention suddenly developed, which necessitated internal ureterostomy. However, perforation of the small intestine occurred two weeks after the surgery and the patient died of severe diffuse purulent peritionitis.

At autopsy, an about fist-sized tumor mass was found in the pelvic cavity, which extended continuously to the walls of the urinary bladder and diffusely to the soft tissues of the palvic cavity. Furthermore, multiple lymph node metastases were found in the pelvic, retroperitoneal, hepatic hilar, bronchopulmonary and left supraclavicular regions, and many hematogenous metastases were found scattered in the liver and lungs. In the abdomen a median cutaneous incision wound was widely cleft, and the artificial ureteral fistula failed at their external openings, leading to a direct communication of the fistula with the peritoneal cavity and in consequence giving rise to severe gangrenous diffuse peritonitis. Additional autopsy findings included ascending bilateral acute ureteritis, purulent pyelonephritis and acute splenitis.

Microscopically, the primary carcinoma of the rectum surgically removed showed a picture of papillary adenocarcinoma. In various organs and tissues, particularly in the reticuloendothelial system, moderate PVP storage was noticed predominantly in the form of proliferating foam cells. Furthermore, it deserves special attention that 
massive, mostly vacuolated substances of varying sizes and irregular shapes were deposited in varying degrees in the stromal tissues of the metastatic lesions, especially among hyalinous connective tissues and occasionally intermingled with foam cells.

5) Histological differences between the cases administered with intermediate molecular PVP and those with low molecular PVP. Compared with the PVP storage phenomenon seen in the 27 cases receiving intermediate molecular PVP, microscopical changes in the 7 cases of low molecular

TABLE 6. Processes of extraction and purification of PVP-like material deposited in tissue

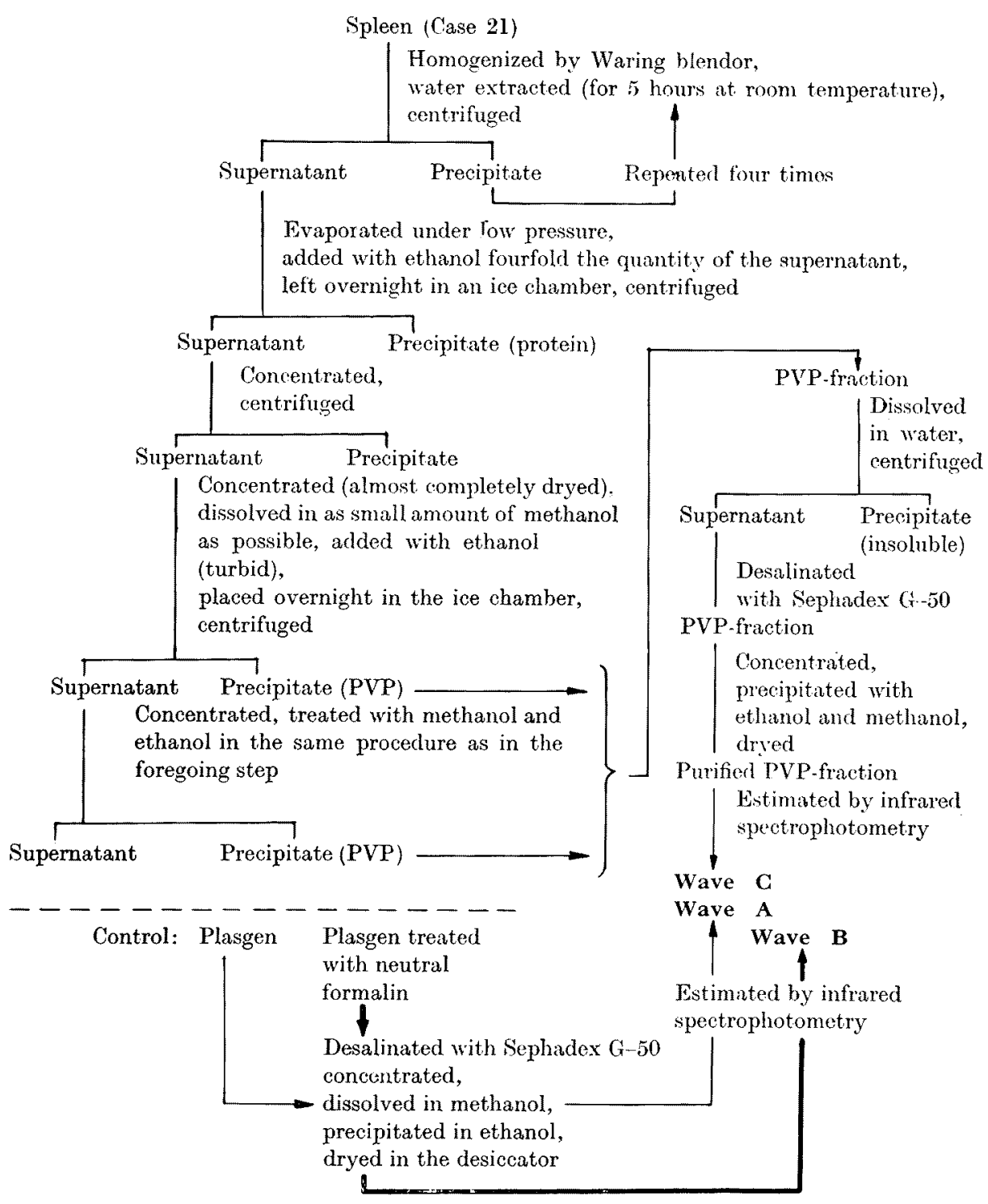


PVP infusion were essentially similar, but appeared less in degree than in the former (see Table 2).

\section{Biochemical Findings}

Attempts at Chemical Identification of PVP-like Material Deposited in Tissues by Infrared Spectrophotonetry

In Case 21 an attempt was made to determine the presence of PVP in formalinfixed specimens of the splenic tissue by an infrared spectrophotometer. Biochemical processes of extraction and purification of the material from the splenic tissue of this case were briefly summarized in Table 6. An infrared spectrophotometer made by Hitachi Litd Co. was used for this identification. Purified PVP-fraction was submitted to spectrophotometry and wave 'C', as indicated in Fig. 13, was confirmed.

As a control material, a solution containing intermediate molecular PVP (the commerical name, 'Plasgen') was desalinated with Sephadex G-50, highly concentrated, dissolved in methanol, precipitated by ethanol and then dryed in a desiccater. The PVP solution purified by these procedures was estimated by the infrared spectrophotometer and the result obtained was denoted as wave 'A'. The result of spectrophotometric determination of the same solution pretreated with neutral formalin yielded wave ' $\mathrm{B}$ '.

Comparing the three waves, it is apparent that the pattern of the wave ' $\mathrm{C}$ ' corresponded on the whole with that of the waves ' $B$ ' and ' $A$ '. Thus, the result indicates that the stored material in the splenic tissue is PVP itself.

\section{Discussion}

The results of the present study established the thesaurosis caused by continuous intravenous PVP injections as a pathological entity. ${ }^{28}$ Although clinical manifestations varied considerably from case to case, ${ }^{29}$ the lesions induced by PVP storage had certain well-defined morphological characteristics, which essentially consisted in reticuloendothelial hyperplasia with prominent appearance of foam cells and deposition of vacuolar or basophilic masses, as well as in occasional appearance of multinuclear giant cells and granulomatous change in rare instances. The kidneys were usually involved in the storage.

Because heavy PVP storage may have some unfavorable effects on the organism, a precise knowledge about the relationship between the total dose of PVP administered and the degrees of PVP storage is necessary to determine the upper limit of the total PVP dose which is compatible with its uneventful clinical use. The results of the present study revealed that only slight morphological changes were only rarely encountered in the cases which had received a total PVP dose of less than $70 \mathrm{~g}$. In this respect, the drug seemed to exert little noxious effect on the organism so far as it is used in a quantity of this range. When PVP was given in a dose of 70 to $150 \mathrm{~g}$, slight to moderate proliferation of 
foam cells appeared in the majority of the cases, together with the deposition of vacuolar or basophilic masses in varying intensity. The storage of this extent seemed still to be practically harmless, except in patients whose general conditions were seriously deteriorated on account of surgery, trauma, inflammation or neoplasm. However, in all the cases which had received PVP infusion in a total dose of more than $200 \mathrm{~g}$ heavy and extensive PVP storage was found to have developed throughout the reticuloendothelial system, frequently producing irreversible lesions. In such cases, it may be reasonable to assume that heavy PVP storage results in blocking the specific functions of the roticuloendothelial cells and further in impairing the resistance of the organism. ${ }^{20,28}$

In their studies on the morphological changes in human bodies due to repeated intravenous PVP infusions, Jacklen, ${ }^{23}$ Tränckner $^{26}$ and Hïsselmann ${ }^{22}$ already pointed out that the changes occurred more intensely in inflammatory foci, and we also confirmed microscopically their observations in our own cases. In agreement with our previous observations, ${ }^{28}$ it was also noted in the present study that numerous histiocytes proliferating in acute inflammatory foci phagocytized PVP particles and were subsequently transformed into foam cells. In chronic inflammatory foci, massive and mostly basophilic deposits were retained predominantly, giving the foci a granulomatous character. ${ }^{23,28}$ On the basis of these findings, we may most reasonably assume that PVP storage in acute inflammatory foci leads to functional depression or blockade of the local reticuloendothelial cells. As a result, the repair process of the inflammatory foci is markedly retarded and the defense mechanism of the body against inflammation is also impaired. Chronic inflammatory foci, when complicated further with granulomatous lesions of foreign body type due to PVP storage, are subjected to distinct delay of their repair process and occasionally give rise to irreversible lesions.

In the surgical wounds of our cases, we could observe the storage changes similar to those seen in the inflammatory foci, though less remarkable in degree than in the latter. ${ }^{26}$ The microscopical findings of the wounds wero essentially the same as those of the reticuloendothelial system and were almost in agreement with the description of Tränckner. ${ }^{26}$ In the wounds, granulation tissues were found to be incomplete. The repair process of the wounds is also markedly disturbed by PVP storage. This is evidenced by cleaving incision wounds of the skin or by separation to anastomosed parts, which were often observed in our surgical cases, especially when PVP had been infused in a total quantity over $70 \mathrm{~g}$.

The similar changes were demonstrated evidently in the strumal connective tissues of neoplasms. On the other hand, in biochemical investigation on the distribution of PVP in human body with carbon-14 labeled PVP-macrose as a tracer, Loeffler and Scudder ${ }^{30}$ presented an interesting result that the labeled PVP accumulated predominantly in neoplastic tissues. The result is in agreement with the microscopical findings confirmed by us. On the basis of our observation, it is further concluded that wide-spread tumor metastases, as documented in the representative case, were often induced in other cases of neoplasmas, particularly 
of carcinomas, in association with marked PVP storage. These results indicate that heavy PVP storage remarkably inhibits the specific functions of the regional histiocytes in the stromal comnective tissues of neoplasm and promotes widespread tumor metastases and dissemination. Generalized suppression of the function of the reticuloendothelial system brings about the decrease of resistance force of the organism. In regard to the question about the effect of PVP on the spread of tumor, we are now conducting an experimental study with a transplantable tumor.

As to the occurrence of the PVP storage in the renal tissue, there are several reports in the literature, ${ }^{20,21,31-35}$ which roughly coincide with the microscopic findings obtained in the present study. The findings are characterized by vacuolar swelling and degeneration of the tubular epithelia, multiple basophilic casts in the tubules, mesangial thickening with occasional deposits of small vacuolar particles and proliferation of foam cells in the glomeruli. To this condition, the terms 'Kollidonnephrose' and 'Peristonnephrose' have been hitherto applied in the German literature. ${ }^{25,34}$ Besides, the present authors found out peculiar, not previously described microscopical changes ${ }^{28}$ : nodular lesions similar to those usually seen in diabetic glomerulosclerosis in 2 cases, intraglomerular capillary hemorrhage in 2 and microaneurysms of the glomerular capillaries in one. In survey of the literature, these glomerular involvements have never been documented in human cases, although in $1952 \mathrm{Brass}^{21}$ succeeded in experimental production of a glomerular alteration in rabbits closely resembling the nodular lesions by repeated intravenous injections of PVP.

In elucidating the PVP storage phenomenon, the fate of the compound in vivo is an important problem. There has been much controversy about the problem. Some research workers ${ }^{6}$ emphasized that PVP was almost completely excreted by the kidney in short periods, to the major part in a few days, and at longest within several months.9.36 On the other hand, Ammon and his coworkers ${ }^{5,8}$ in their experimental studies of animals arrived at the conclusion that repeated intravenous injections of PVP produced an irreversible storage phenomenon, because massively stored PVP could not be excreted by the kidney. On the basis of our observation, it is, however, obvious that in almost all cases discontinuance of the intravenous infusion of PVP resulted in gradual regression of storage lesions. In the regressive lesions foam cells gradually decrease in number and finally disappeared, but basophilic deposits remained almost unchanged in tissues for a long period, approximately to 8 months after the final PVP infusion. ${ }^{28}$ Tränckner $^{26}$ reported such a finding in a case examined about 3 years after the last PVP injection and Hüsselmann ${ }^{22}$ demonstrated a similar change in his case after about 1 year and 3 months' interval. From these reports, it seems apparent that once stored PVP, though decomposed and removed to some degree by reticuloendothelial cells, are retained to the major part in the body for a long time.

Finally, we will discuss the pathogenesis of PVP storage disease. As 
repeatedly stressed above, it is apparent that the characteristic morphological changes in various organs and tissues, particularly throughout the reticuloendothelial system and in the kidney, are to be interpreted as a storage phenomenon. resulting from continued intravenous administration of PVP. The main underlying mechanism in the development of storage is sought in phagocytosis of substances of foreign body nature by the reticuloendothelial cells, because it belongs to the functions inherent to them. However, the process is influenced on the other hand by the indigestibility of the compound in the cells. Hence, with increasing total doses of intravenously given PVP, the reticuloendothelial cells are forced to proliferate to compensate the increased load, so that a kind of reactive storage reticuloendotheliosis ${ }^{37-39}$ characterized by proliferation of foam cells develops, which is further complicated by the inflammatory reaction against a foreign body. However, in 1952 Jeckeln $^{23}$ investigated microscopically 16 autopsy cases of children with PVP storage and pointed out as noteworthy changes marked activation of mesenchymal cells, especially of the vascular endothelia in the form of granulomatous endoangitis, tissue eosinophilia and interstitial pneumonitis. On the basis of these microscopical findings, he presented a working hypothesis that an allergic phenomenon might participate in the PVP storage disease. He regarded PVP as a hapten capable of acquiring an antigen character when combined with the body protein in vivo and of giving rise to an antigen-antibody tissue reaction. In agreement with Hiisselmann ${ }^{22}$ and Tränckner, ${ }^{26}$ however, we could not obtain such microscopical findings in favor of the allergic theory. We could observe only plasma cell infiltration mostly in the lymph nodes or spleen. Since the relationship of PVP to mobilization of plasma cells has not been clearly explained and some research workers, on the other hand, have pointed out an affinity of the compound to globulin fractions in serum, ${ }^{26}$ it does not seem adequate entirely to discard the allergic theory at the present step of investigations.

\section{Summary and Conclusion}

In an attempt to study the development of PVP storage phenomenon, 34 autopsy cases in which varying total doses of intermediate or low molecular PVP had been administered were examined from clinical, pathological and biochemical viewpoints. Out of these cases, 27 cases had had intravenous infusion of intermediate molecular PVP and the remaining 7 had received low molecular PVP. In the former group, 6 cases of intravenous PVP infusion in a total dose over $200 \mathrm{~g}$ were the most useful for the present study, since they exhibited usually heavy PVP storage.

Macroscopically, there was no conspicuous findings that could be attributed to this agent except for slight splenomegaly. However, microscopical examination revealed marked proliferation of foam cells in various organs and tissues, particularly throughout the reticuloendothelial system, furthermore 
deposition of vacuolar masses, often with basophilic tinge, and occasional appearance of multinuclear giant cells and granulomatous lesions. In our cases, it seemed very likely that the larger the total dose of intravenously given PVP was, the more pronounced was the storage changes induced. Furthermore, inflammatory foci, as well as surgical wounds, were remarkably involved in PVP storage. Similar lesions were frequently observed in the stromal connective tissues of neoplasmas. Materials stored in tissues were identified as PVP itself by histochemical techniques and by infrared spectrophotometry.

In the renal tissues, we confirmed also distinct storage changes similar to those previously described as 'Kollidonnephrose' or 'Peristonnephrose' in the German literature, and obtained further peculiar, previously not described findings, namely the nodular lesions resembling those seen in the Kimmelstiel-Wilson syndrome, microaneurysms of the glomerular tufts and multiple hemorrhages of glomerular capillaries.

In almost all the cases receiving more than $200 \mathrm{~g}$ of PVP in total, a heavy PVP storage usually developed. In such cases it is reasonable to assume that the storage results in blocking the specific functions of the reticuloendothelial cells and further in lowering the resistance force of the living body. For the same reason, it seems probable that the repair process of the inflammatory foci and surgical wounds is markedly retarded by and interfered with the storage. There was the evidence that PVP storage promoted the growth and dissemination of already present cancers.

\section{Acknowledgment}

The authors wish to express their deepest appreciation to Dr. Y. Nagai, Department of Biochemistry, Fukushima Medical College, and Dr. T. Tanaka, Toowaeiyo Co. Ltd., who kindly performed the biochemical examination of the substance deposited in tissue by infrared spectrophotometry.

\section{References}

1) Reppe, W. Neue Entwicklungen auf dem Gebiet der Chemie des Acetylens und Kohlenoxyds, Springer-Verlag, Berlin-Gättingen-Heidreberg, 1949, Chemie und Technik der Acetylen-Reaktionen, Verlag Chemie Gmb H. Weinheim/Bergstrs.,1952. Cit. by Yamaguchi, T., Tabuchi, Y. \& Ikeda, I., in: PVP (Polyvinylpyrrolidone); its basic and clinical application. Sogorinsho (Jap.), 1956, 5, 1980-1994.

2) Reppe, W. Polyvinylpyrrolidon, in Angewandte Chemie und Chemie-IngenieurTechnik (Jap.), (edited by Kyorinseiyaku K.K.) 1954, pp. 1-5.

3) Yamaguchi, Y., Tabuchi, Y. \& Ikeda, I. PVP (Polyvinylpyrrolidon); its basic and clinical application. Sogorinsho (Jap.), 1956, 5, 1980-1994.

4) Hecht, G. \& Weese, H. Münch. med. Wschr., 1943, 90, 11. Cit. by R. Ammon, \& W. Müller, in: Der Einfluss hoher Peristongaben auf den Kaninchenorganismus unter besonderer Berücksichtigung der Speicherorgane. Dtsch. med. Wschr, 1949, 74, $465-467$.

5) Ammon, R. \& Braunschmidt, G. Das Schicksal des Peristons im Organismus, Biochem. Z., 1949, 319, 370-467.

6) Schubert, R. Neue med. Welt., 1950, 19, 78. Cit. by Y. Yamaguchi, Y. Tabuchi, \& I. Ikeda. in: PVP (Polyvinylpyrrolidon); its basic and clinical application. 
Sogorinsho (Jap.), 1956, 5, 1980-1994.

7) Weese, $H$. Indifferente Kolloide in Chirurgie und innerer Medizin. Itsch. med. Wschr., 1951, 76, 757-761.

8) Ammon, R. \& Müller, W. Der Einfluss hoher Peristongaben auf den Kaninchenorganismus unter besonderer Beruicksichtigung der Speicherograne. Dtsch. med. Wschr., $1949,74465-467$.

9) Barfuss, F. \& Eichler, O. Periston bei wiederholter Darreichung. Arch. exp. Path. Pharmak., 1949, 206, 346-356.

10) Bargmann, W. U̇ber Milzveränderungen nach Zufuhr des Blutflüssigkeitsersatz. Virchows Arch. path. Anat., 1947, 314, 162-166.

11) Davin, H.A., Seligman, A.M. \& Fine, J. Polyvinyl pyrrolidone as a plasma expander (Studies on its excretion, distribution and metabolism). New Engl.J. Med., 1952, 247, 921-929.

12) Heinlein, H. \& Hübner, G. Nachweis der Periston im Blut, Harn und Gewebe. Beitr. path. Anat., 1958, 119, 301-305.

13) Hübner, G. Ùber die Bildung organischer Substanzen bei der Kollidonspeicherung. Virchows Arch. path. Anat., 1960, 333, 29-39.

14) Janesô, N. Speicherung; Stoffanreicherung im Retikuloendothel und in der Niere. Akademiaki kaido (Budapest), 1955, pp. 148-149 and p. 440.

15) Janesô, N. Storage of protein and vinylpolymers in histiocytes and in the renal epithelium. Acta medica Hung., 1955, 7, 173-210.

16) Nelson, A. A. \& Lusky, L.M. Pathological changes in rabbits from repeated injections of periston (polyvinyl pyrrolidone) or dextran. Proc. Soc. exp. Biol. Med., 1951, 76, 765-767.

17) Stern, K. Effect of polyvinylpyrroldione on reticuloendothelial storage. Proc. Soc. exp. Biol. Med., 1952, 79, 618-623.

18) Wrage, K. H. Untersuchungen über die Unterschiede in der Speicherung von Periston und Periston N. Frankf. Z. Path., 1955, 66, 246-250.

19) Bennhold, H. U̇ber die Bedeutung von physiologischen und von künstlichen Kolloiden (Periston) zur Regelung von Transportvorgängen im tierischen Organismus. Dtsch. med. Wschr., 1951, 76, 1485-1487.

20) Tränckner, K. Experimentelle Untersuchungen zur Frage der Peristonspeicherung in den Mitochondrien der Nierentubuli. Z. ges. exp. Med., 1954, 123, 91-100.

21) Brass, K. Morphologische Befunde beim Menschen und Kaninchen nach wiederholter Periston-(Kollidon-)Zufuhr. Frankf. Z. Path., 1952, 63, 59-112.

22) Hüsselman, H. Speicherungserscheinungen beim Menschen nach Periston. Klin. Wschr., 1952, 30, 801-808.

23) Jeckeln, E. U̇ber gewebliche Äusserungen des Säuglingsorganismus nach wiederholten Peristongaben. Virchows Arch. path. Anat., 1952, 322, 529-562.

24) Schoen, H. Organveränderungen beim Säugling nach Zufuhr von Periston. Klin. Wschr., 1949, 27, 463-468.

25) Tränckner, K. Morphologische Nierenveränderungen nach Periston beim Menschen. Frankf. Z. Path., 1954, 65, 80-96.

26) Tränckner, K. Das Schicksal des Peristons im menschlichen Körper nach histologischen Untersuchungen. Frankf. Z. Path., 1954, 65, 62-79.

27) Kojima, M. \& Takahashi, K. Concept of xanthomatosis. Saishin Igaku (Jap.), $1965,21,522-536 ; 812-831$.

28) Kojima, M., Takahashi, K., Honda, K. \& Ogawa, T. Influences of PVP infusion on the organism. Saishin Igaku, (Jap.) 1965, 20, 453-468.

29) Watanabe, $K$. Clinical studies on 144 cases using plasma expander (PVP). Nippon Yuketsugakkai Zasshi (Jap.), 1966, 12, 173-192.

30) Loeffer, R.L. \& Seudder, J. Excretion and distribution of polyvinyl pyrrolidone in man, as determined by use of radiocarbon. Amer. J. clin. Path., 1953, 23, 311-321.

31) Hecht, G. Úber den Mechanismus der Kollidonausscheidung der Niere. Arch. exp. Path. Pharmak., 1955, 226, 46-61. 
32) Hecht, G. \& Scholtan, W. Úber die Ausscheidung von Polyvinylpyrrolidon durch die normale Niere. Z. ges. exp. Med., 1959, 130, 577-603.

33) Hübner, G. Morphologische und histochemische Untersuchungen zur Kollidonausscheidung durch die Nieren. Beitr. path. Anat, 1960, 122, 106-122.

34) Hübner, G. Elektronenmikroskopsiche Untersuchungen zur sog. Kollidonnephrose. Beitr. path. Anat., 1962, 126, 1-28.

35) Schubert, R. Verhalten von neidermolekulären Polyvinylpyrrolidon (Kollidon) in Harn und Serum bei 60 Nierengesunden. Z. ges. exp. Med., 1960, 132, 468 472.

36) Fresen, O. \& Weese, H. Das gewebliche Bild nach Infusion verschiedener Kollidonfraktionenen (Periston N, Periston, hochvisköses Periston) beim Tier. Beitr. path. Anat., 1952, 122, 44-50.

37) Kojima, M. Pathological reticuloendothelial system (reticuloendotheliosis). Nihon Ketsuekigaku Zensho (Jap.), 1964, 3, 325-374.

38) Kojima, M. \& Takahashi, K. Concept of reticuloendotheliosis. Tohoku J. exp. Med., 1965, 85, 120-142.

39) Kojima, M. \& Takahashi, K. Storage reticuloendotheliosis. Rinsho kagaku (Jap.), $1967,3,701-726$.

\section{Legends}

Fig. 1. Case 24. Liver. In widely dilated sinusoidal spaces numerous foam cells proliferate with occasional deposition of amorphous vacuolar masses, and a giant cell is seen in the center of the figure. The liver cells become markedly atrophied, degenerated, and in places are found to have disappeared.

Fig. 2. Case 21. Liver. The normal hepatic structure is almost completely destroyed and replaced by a tremendous number of foam cells containing many PVP-like granules. The hepatic cells reveal also a foamy appearance and newly formed bile ducts are dispersedly present.

Fig. 3. Case 27. Spleen. The sinusoidal endothelia are prominently swollen and show a foamy appearance mostly with basophilic contents.

Fig. 4. Case 24. Lymph node. Remarkable proliferation of foam cells particularly in the lymph sinuses.

Fig. 5. Case 19. Lymph node. Small clusters of multinuclear giant cells loaded with many fine or coarse phagocytic granules and small amorphous masses mostly with basophilic tinge.

Fig. 6. Case 14. Bone marrow. The normal bone marrow tissue is diffusely infiltrated by a large number of proliferating foam cells, some displaying basophilio contents in the cytoplasm.

Fig. 7. Case 24. Inflammatory lesion of the peritoneum. Diffuse proliferation of foam cells and histiocytes.

Fig. 8. Case 26. Lung. A large number of foam cells proliferate in the alveolar spaces and within the alveolar septa, occasionally intermingled with a number of multinuclear giant cells.

Fig. 9. Case 14. Urinary bladder. Massive deposition of a large amount of basophilic substance accompanied by a few giant cells.

Fig. 10. Case 27. Kidney. Vacuolar swelling and degeneration of the epithelial cells of the distal convolusion of tubules.

Fig. 11. Case 24. Kidney. Mesangial thickening and proliferation of foam cells, the latter being found scattered in the lower glomerulus or nodularly grouped in the upper.

Fig. 12. Case 24. Kidney. Nodular lesion of the glomerulus closely resembling one usually seen in diabetic glomerulosclerosis. 


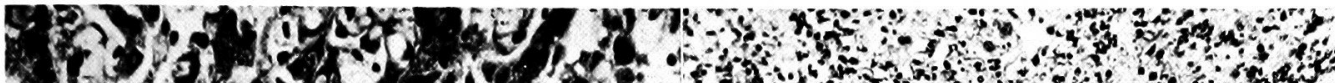

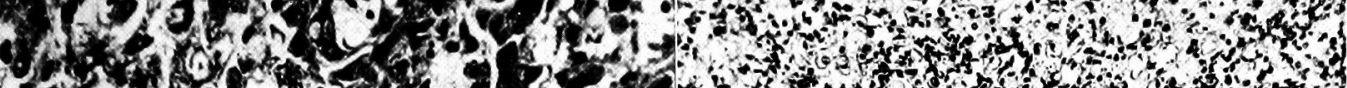
6.

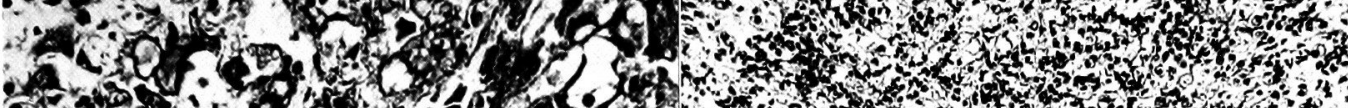

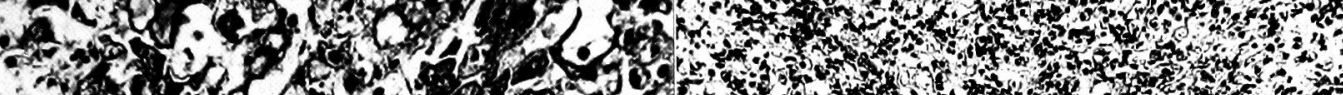

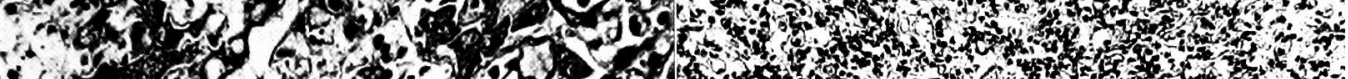

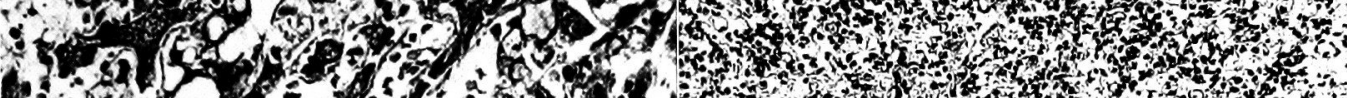

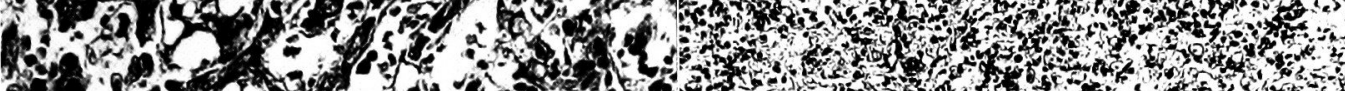

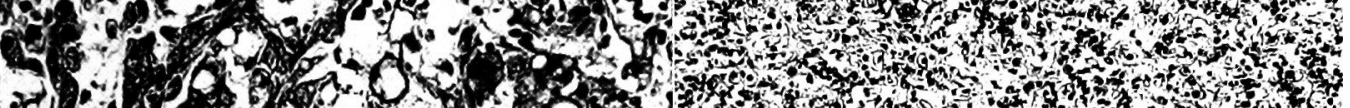
3E)

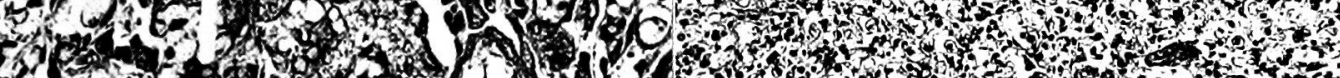

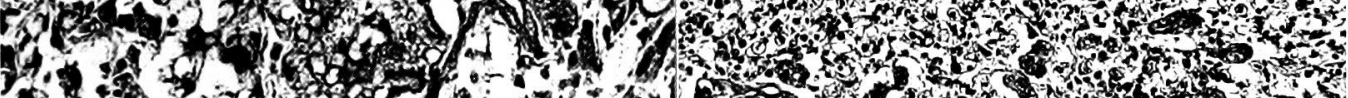

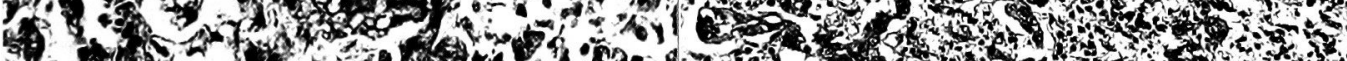

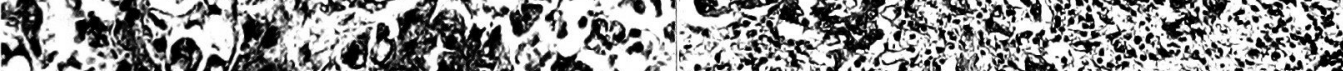

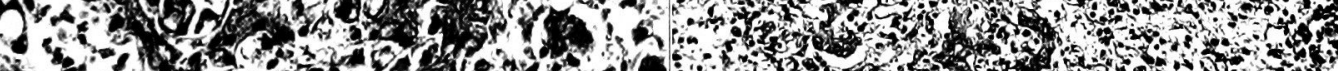

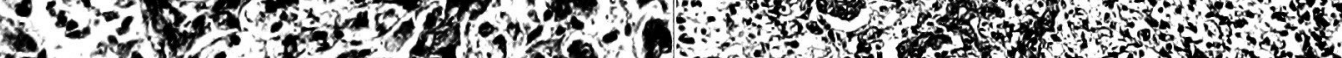
20.

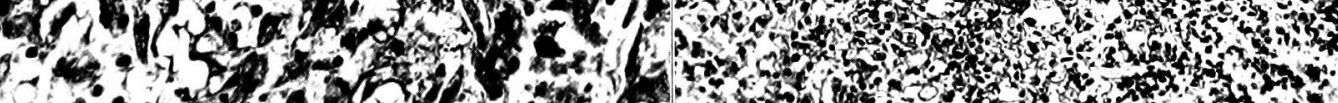

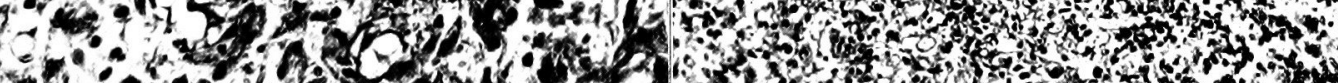

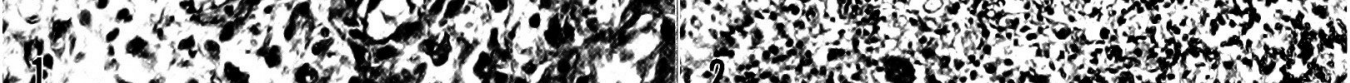
(f)!

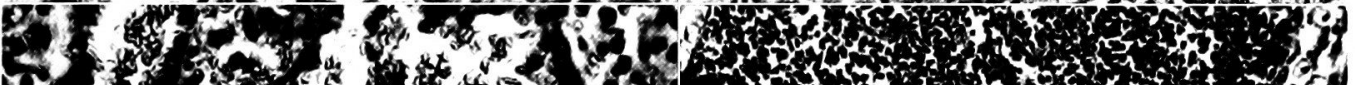
(4) 1 .

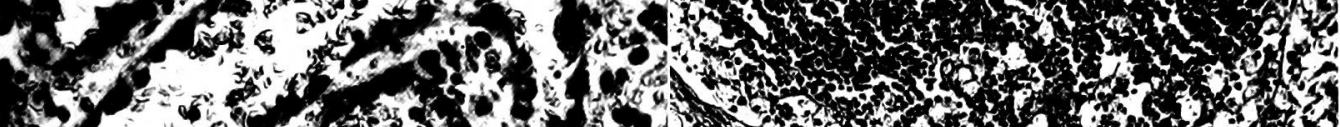
153

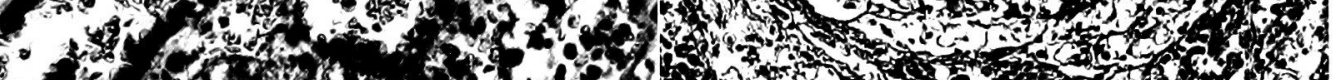

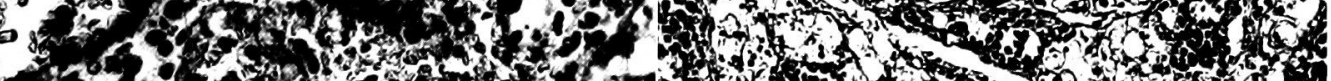

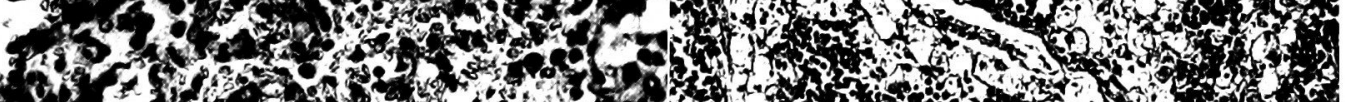

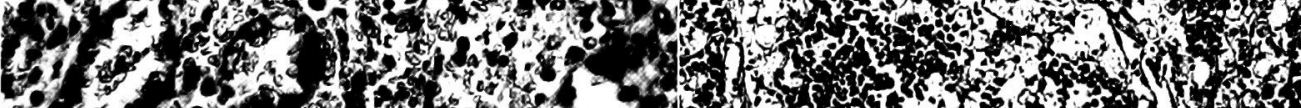

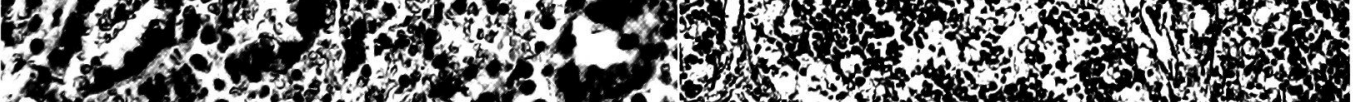

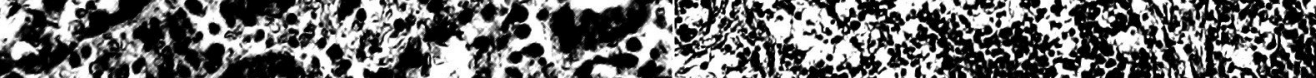

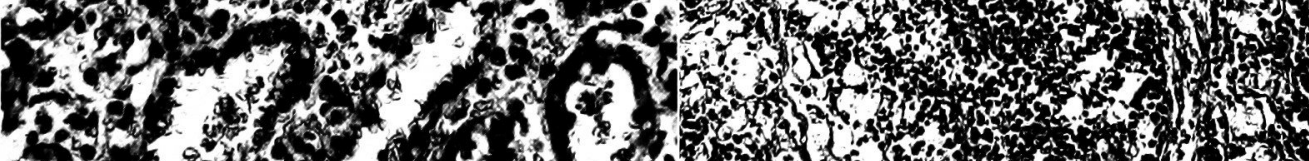

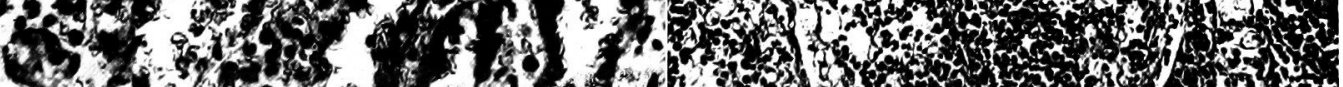

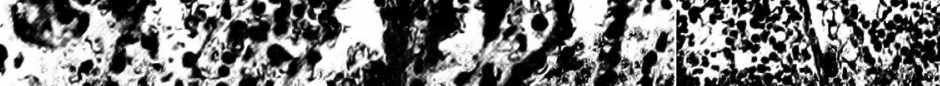

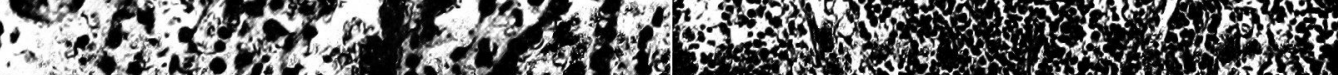

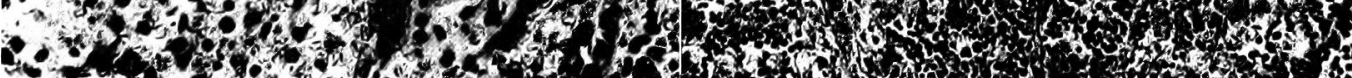

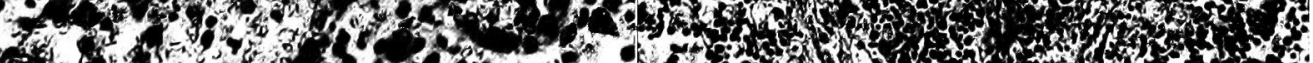

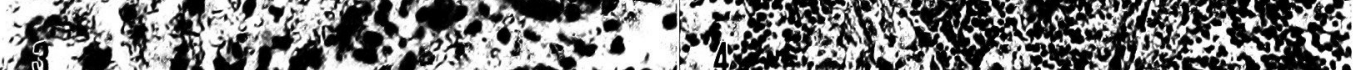

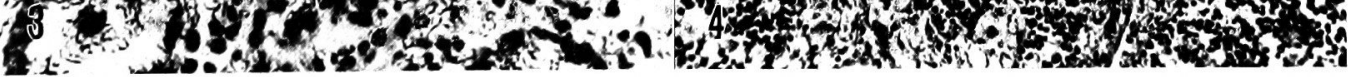




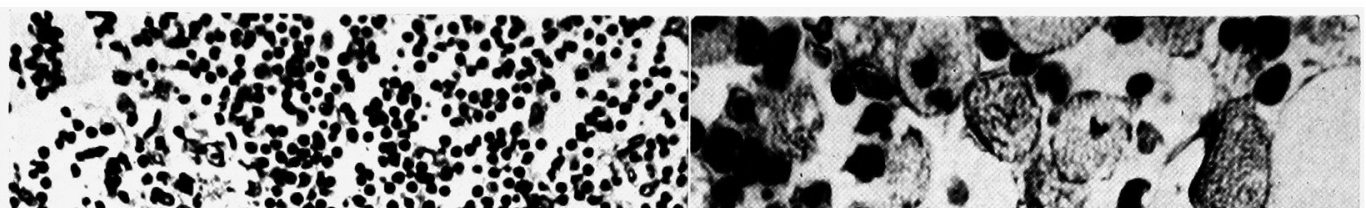

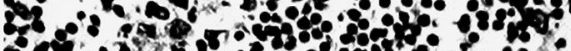

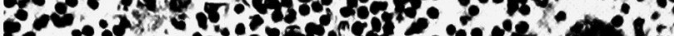

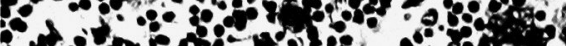

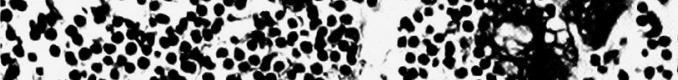

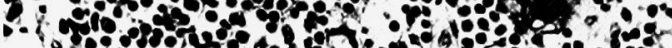

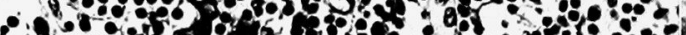

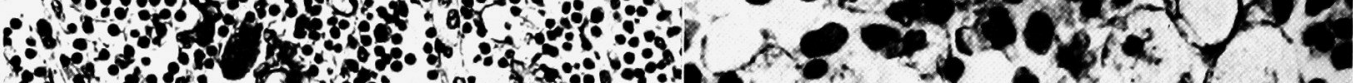

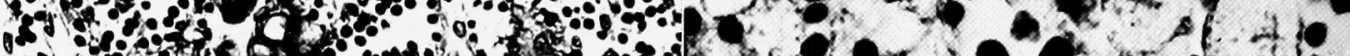

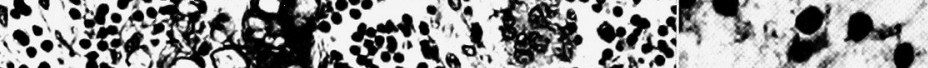

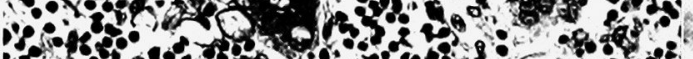
of

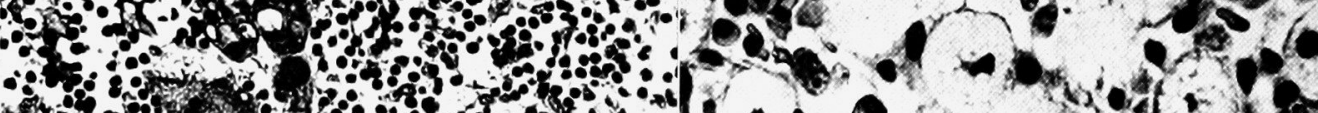

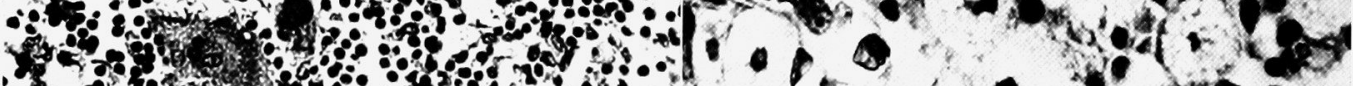

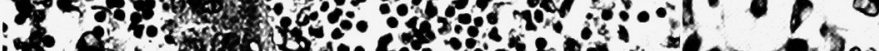

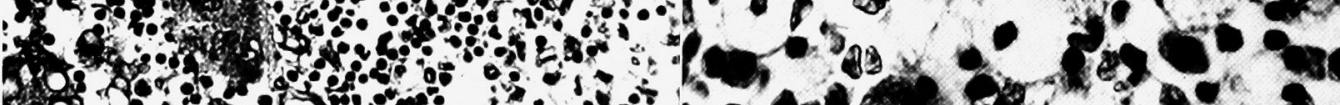
12 . Jan

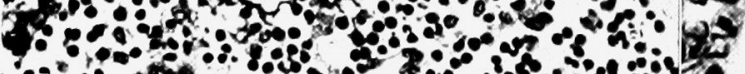

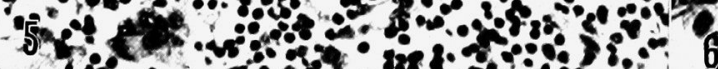

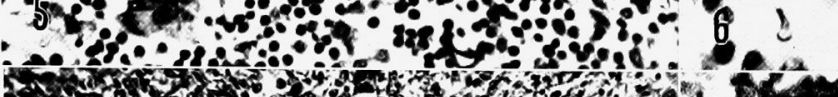
(2)

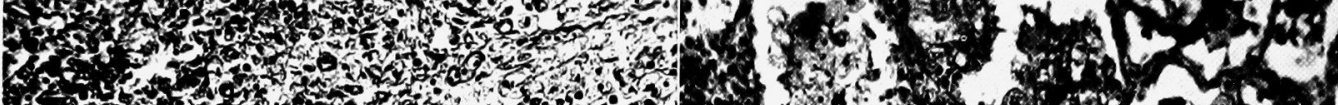

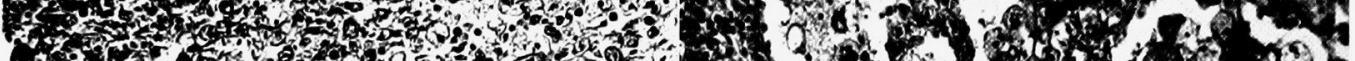

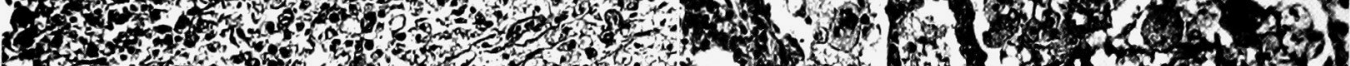
7.

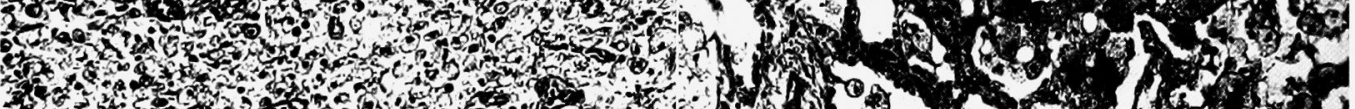

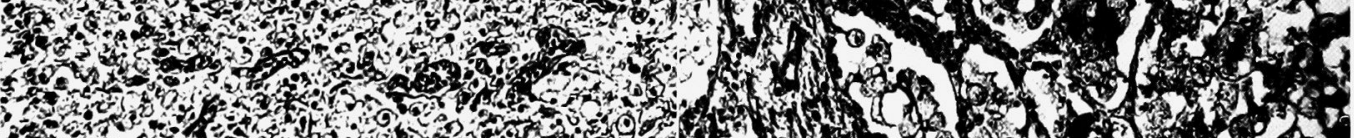

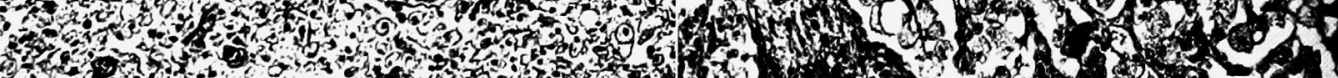
7.

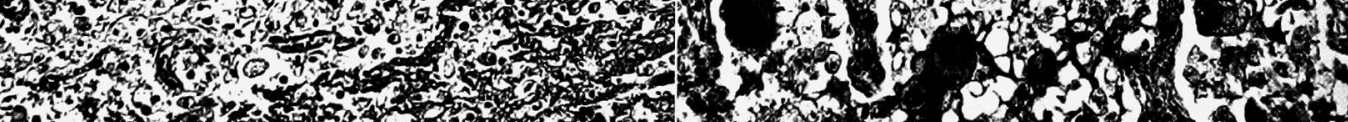

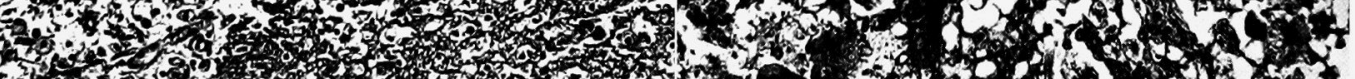

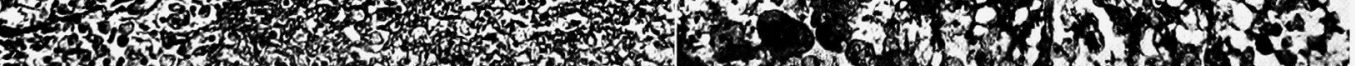
15. 20, 3.7,

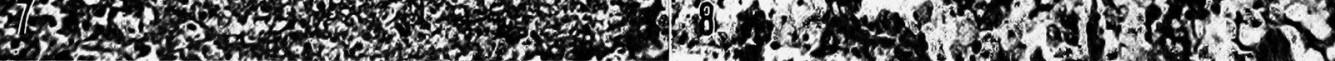




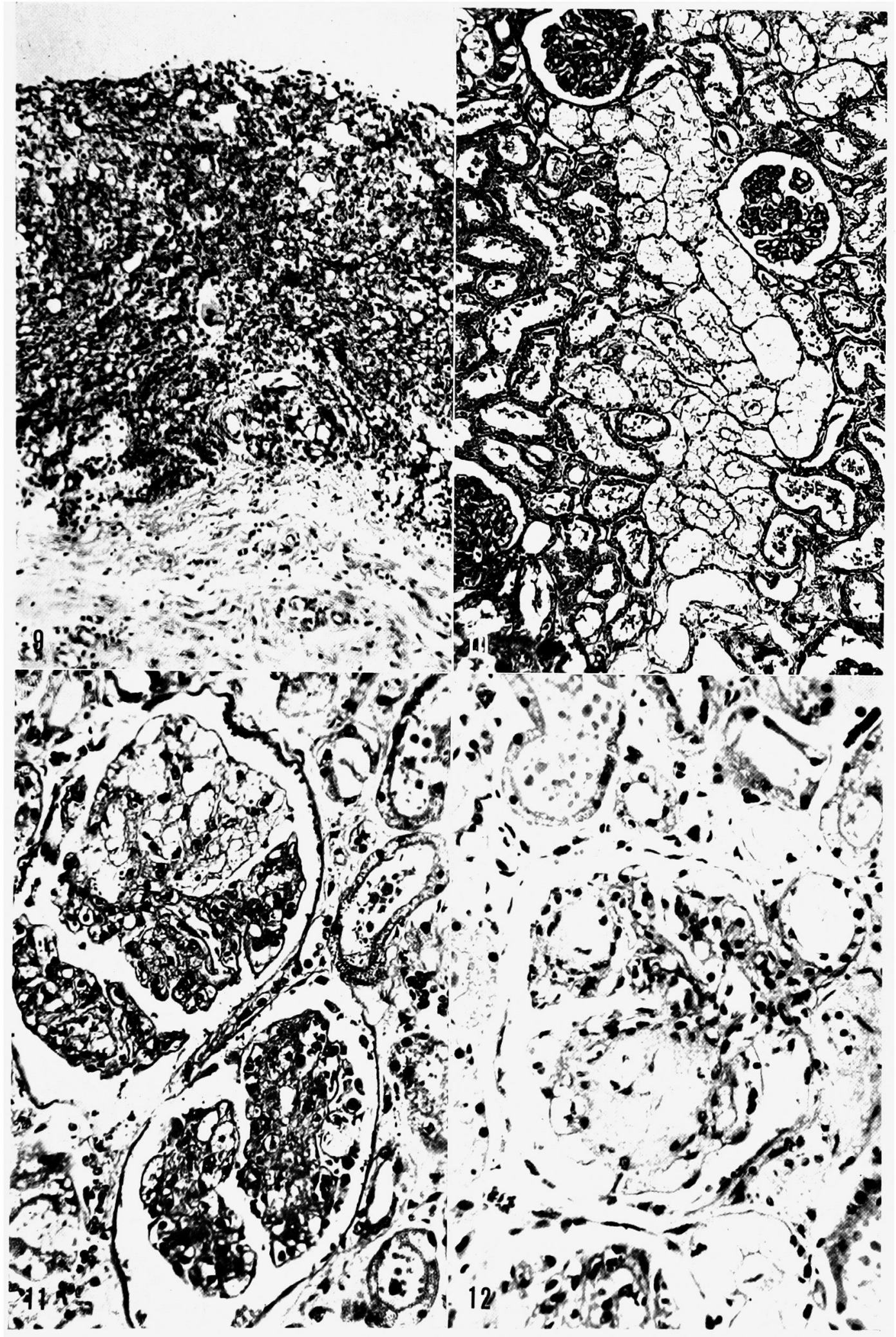




\section{INFRARED SPECTROPHOTOMETER}

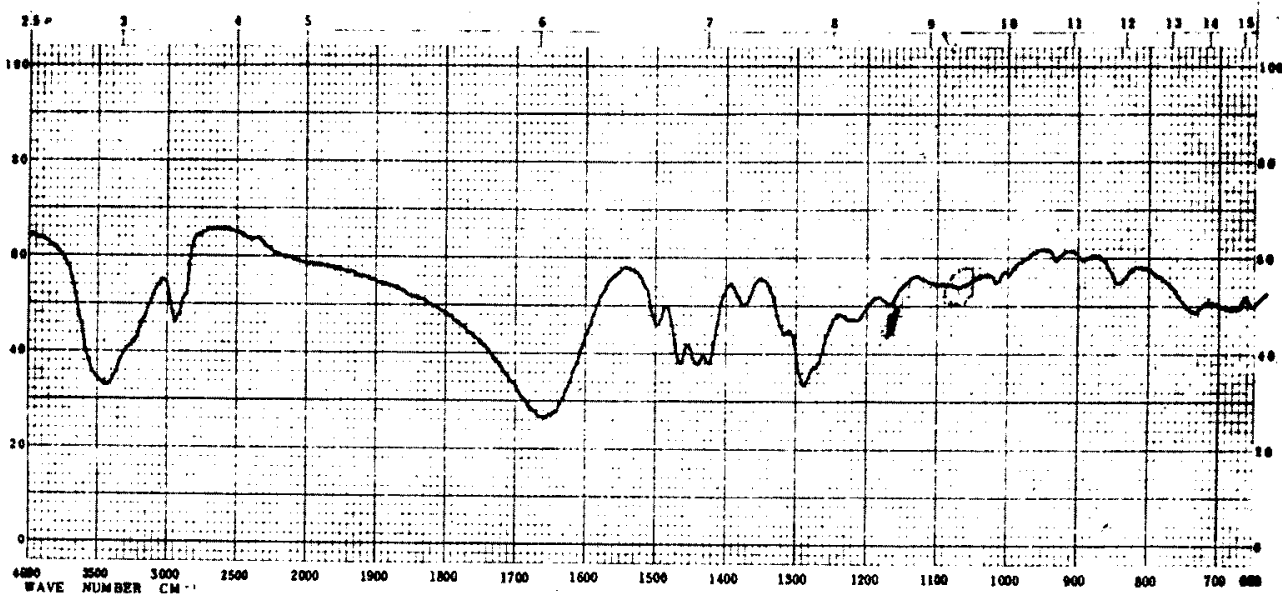

A. PVP

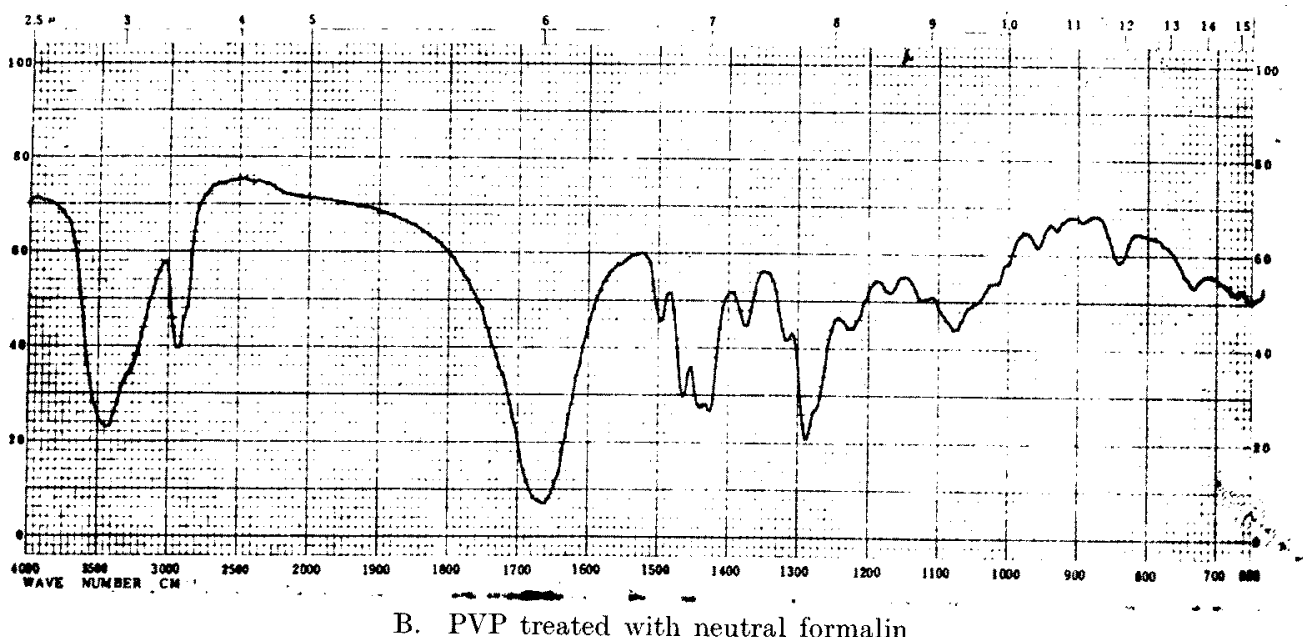

B. PVP treated with neutral formalin

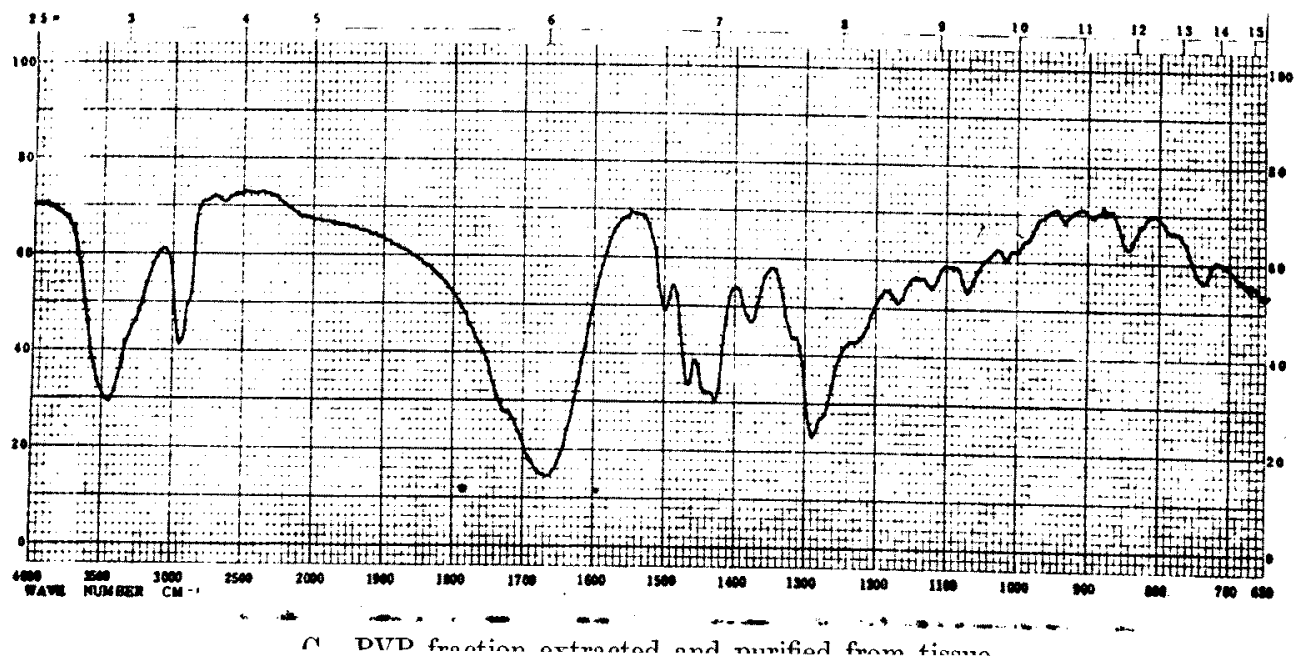

